\title{
Assessment of the Effectiveness of Adjustment Programs at the Core of the Greek Economy
}

\author{
Aggelos Kotios ${ }^{1}$ George Galanos ${ }^{2}$, Thomas Poufinas ${ }^{2 *}$ \\ ${ }^{1}$ Department of International and European Studies, University of Piraeus, Piraeus, Greece \\ ${ }^{2}$ Department of Economics, Democritus University of Thrace, Komotini, Greece \\ Email: *tpoufinas@gmail.com
}

How to cite this paper: Kotios, A., Galanos, G. and Poufinas, T. (2018) Assessment of the Effectiveness of Adjustment Programs at the Core of the Greek Economy. Modern Economy, 9, 1548-1591. https://doi.org/10.4236/me.2018.99098

Received: August 13, 2018

Accepted: September 18, 2018

Published: September 21, 2018

Copyright (c) 2018 by authors and Scientific Research Publishing Inc. This work is licensed under the Creative Commons Attribution International License (CC BY 4.0).

http://creativecommons.org/licenses/by/4.0/

(c) (i) Open Access

\begin{abstract}
Despite the seven-year implementation of three adjustment programs to address the sovereign debt crisis, the Greek economy is still in a prolonged recession and faces problems of competitiveness, political stability and social cohesion. At the same time, the fiscal adjustment policy did not solve the original problem of public debt. On the contrary, as recent evidence shows, the country's ability to service its debt has deteriorated. The causes of the crisis and the failure of the selected economic stabilization policies are a multidimensional and interrelated complex. The Greek economy has supported its growth in recent decades mainly in domestic consumption, with little presence in areas with high added value and extrovert features, focusing mainly on traditional business sectors with limited innovation characteristics. In this study we will try on reasonable arguments but also with a series of statistical data and indicators from sources such as the Organization for Economic Cooperation and Development (OECD), the World Bank, the World Economic Forum (WEF) and the Greek authorities to analyze the course of the Greek economy, evaluate the results of the selected policies and to formulate appropriate policy proposals.
\end{abstract}

\section{Keywords}

Effectiveness, Greek Economy

\section{Introduction}

By the end of 2009, Greek politics realized that the continuously growing public debt had reached such levels that it was almost impossible to manage, and drastic actions were required in order to put under control the whole situation. At the same time, a number of other European countries faced financial problems, 
with each case being different from the others. Since then, Greece had to ask for external help, and proceeded with a series of adjustment programs, in co-operation and with the guidance of a group of creditors comprised of EU institutions and the International Monetary Fund (IMF). However, today, with the third such adjustment programme under implementation, the problems of the country are far from being solved. Sustainable growth is under question, liquidity is absent, political stability and social cohesion is threatened. The promoted macroeconomic policy did not solve the problem of large public debt, but instead plunged the economy into a deep recession, drastically reducing its ability to serve the redemption of its debt [1] [2].

This reality has prompted the scientific community to look for the reasons behind this unpleasant development but also to investigate the correlation with other countries such as Cyprus, Portugal and Ireland which, as mentioned before, have been able to successfully implement their own adaptation programs and today are enjoying a much more improved situation. This comparison raises a series of questions if the chosen policy mix was the proper one for Greece, or if country's resistance to the attempted changes was indeed the main reason for the limited effectiveness of the programmes [3] [4].

There are different opinions that have been brought forward from several interested parties, with each one of them defending its own point of view. The lenders' side identifies the reluctance of the country to implement the necessary reforms and move towards a more productive and extrovert production model for the country. According to this view, an investment-friendly environment, with the adoption of liberal policies, reductions in public spending and an increase in taxation are required in order for the country to be stabilized and its economic situation to start improving [1] [5] [6].

On the contrary, another group of researchers based on the Keynesian theory, states that the failure of resolving but on the contrary perpetuating the problem in the country, is mainly due to the inappropriate policy mixture, as it has been imposed on the country to implement it. Since Greece is in the Eurozone and cannot pursue an independent monetary policy, domestic demand constraint and internal devaluation were the chosen key drivers, which however led to a deep recession, with extremely reduced salaries and pensions, thus reducing consumption, raising unemployment and establishing the foundations of the negative economical spiral that Greece is facing. This vicious cycle of recession and the ongoing decline of individuals' purchasing power, together with the total absence of counter-cyclical policies that could break this vicious circle, perpetuate this negative trend, not allowing the economy to escape of the recessional vortex [7] [8] [9].

Nowadays another approach is being shaped, which without rejecting the basic arguments of the previous two theories, it mostly focuses on the very structural elements of Greek economy. It criticizes both traditional approaches for insisting in focusing to curing the effects of the problem rather than treating the 
real cause instead [10] [11] [12] [13] [14]. The representatives of this theory emphasize the need to target exactly on the detection and addressing of the root causes as the only realistic approach for the country to finally come out of the recession spiral. The most notable structural problems of Greek economy is its production structure, which is highly introverted and with little seeds of innovation in the mix, its inefficient organizational model, the intense state interventions and control of the economy, the slow and resource demanding public sector, as well as the troubled political reality [15] [16].

In this article we aim in analysing the main characteristics of the Greek economy, based on indicators and statistical data, from sources such as the OECD [17], the IMF, the WEF, the World Bank and the Hellenic Statistical Authority, as well as observations, together with the exploitation of the international bibliography. We will attempt to assess the applied policies results, their interaction and coherence with the country specific characteristics. We will try to outline proposals for more suitable potential policies, aiming in treating Greek economy inefficiencies and drawbacks that will radically help it overcome the crisis, and thus terminate the recessional trends that cause such tribulation to its functionality in general and to its citizens individually.

\section{The Results of the Adjustment Policy in Greece}

In late 2009 the financial crisis in Greece burst out, alerting the total of the European Union (EU), but mainly the Eurozone fellow countries. The causation was the reveal that the public deficit will be much higher than what was initially predicted, and of course allowed from Eurozone rules. Following this admittance, all parts started to take into account the for-long accumulated problems of Greek economy and its production model. Greece's low competitiveness, the large and inefficient public sector, the awkward business model, the discouraging investment environment, the complicated and repelling legal framework, the perplexing and binding labor legal framework, and the distortions in financial and services markets, soundly surfaced [18] [19] [20] [21]. A clear indication of the structural problems of the Greek economy was the close link between fiscal deficit and the current account deficit, a phenomenon which was extremely intense during all previous decade, with the projections for the coming years being anything but promising.

After these conclusions were made obvious to everybody a twofold strategy was requested. First to reform the fiscal operations, and second to enhance the Greek economy competitiveness, adopting as a strategic tool the improvement of internal and external payments balance. Under this approach Greece agreed to three consecutive adjustment programs that secured funding for the Greek state and economy, but mainly shaped a strategy in order for Greece to fix the two above-mentioned problems. These adjustment programs had the following objectives [22] [23] [24] [25]:

1) Short Term Objectives 
a) Restore fiscal balance.

b) Ensure financial stability, and liquidity in the economy.

2) Medium and Long Term Objectives

a) Ensure the recovery of the Greek economy and the servicing of Greece's debt.

b) Restore external imbalances.

c) Improve the competitiveness of the Greek economy.

Policy interventions chosen and applied for Greece can be categorised as follows:

1) Rationalisation of public expenditures, increased tax incomes and succeeding primary surpluses.

2) Exports growth and imports curtail, through internal devaluation. As key tool to be used was the shrinkage of income, aiming in reducing domestic consumption and increasing net prices of imported goods and services.

3) Reforming public sector through improving its efficiency. This includes both lowering operating costs, but also enhancing procedures and promoting reorganisation and modernisation of the respective legal framework.

4) The opening of specific markets, like these of goods, labour, services and capital, in order to enhance competition, reduce unemployment rates, lower goods costs, as long as increase the size of the respective markets.

5) Deregulation of labour market and reduction of the intervening power of labour unions.

6) Extend privatisation of state owned enterprises and other state assets, in order to increase public liquidity and create new opportunities to private sector.

IMF participation in the adjustment programmes heavily characterised the policy mixtures and objectives approved for Greece. However since in these programmes IMF was not the only participant, but acted in collaboration with European Union members and their organisations (namely the European Central Bank (ECB) and the European Stability Mechanism (ESM)) a new policy blend was necessary. In more detail, EU participants had to follow IMF in implementing its standard expansionary policies for supporting demand and investment, through Keynesian policies; however IMF had to take into consideration the principles and limitations of Eurozone and its countries, especially in terms of to deal with such policies [26]. As an outcome of the above and with respect to the objectives and means of the programmes, the selected policy mixture follows the modern neoliberalism principles of Supply-Side Economics, through promoting free market economy, reducing the role of the state, and deteriorating total demand.

One primary parameter for selecting such a policy mixture was the estimation of low intensity recession effects, and for a short period of time, followed by an anticipated dynamic growth which will be the main economy driver. This estimation was based on a number of assumptions like:

1) The empowerment of exports, since internal devaluation was expected to 
turn Greek services and products cheaper, thus more attractive to the markets abroad. In addition, internal demand for them was expected to increase as a result in the drop of the volume of the imported products, which would in turn become less attractive and expensive.

2) Privatisation policies, liberalisation and deregulation of domestic markets, as well as the reform of the public sector were designed as key drivers for attracting direct external investments, thus directly enhancing GDP growth. The improved business operating environment, as well as the reinforced demand for local products and services, was also accounted as a supplementary set of advantages.

3) A growth boom was expected after the successful completion of each adjustment programme. The main idea was that due to the succeeded fiscal adjustment a decrease to the taxation would be obtainable, increasing demand, and as a result enhancing the willingness for investments. This trend was to be combined with lower levels of public debt, enhancing the confidence effect towards the Greek economy, and thus allowing further taxation relief [27] [28]. In addition the reduction of public debt was to transpire in lower interest rates for both public and private lending, improving borrowing terms, especially for businesses. Finally the induced shrinkage of consumption was thought to result in an increase of household and business savings, which in the next phase would be available for investments.

Based on previous international experience after the first shock of public debt bubble burst, a period of recession was certainly expected; with a forthcoming development period however being anticipated, enriched with strong sustainable characteristics, especially if it is compared with the development model applied in the past. Lower public debt and improved debt to GDP ratio characteristics were the goal and the foreseen growth driver.

Howbeit reality evolved in a much different path than the aforementioned one. Recession proved to be much deeper and lasted for a long period of time, in magnitudes that no previous estimation had ever been made. As we can observe in Figure 1 and Figure 2, the total GDP loss for Greece was more than 27\% from 2008 to 2016. Since 2014 the recession was much hollower, while for 2017 strong development rate was expected. Nevertheless as mentioned before, sustainability characteristics of this expected growth are still weak. The sharp recession caused a dramatic increase in unemployment rate, reaching a maximum of more than 25\%, the highest among European Union countries. The most worrying however sign, is the fact that Greece seems unable follow the European trend for strong development and low unemployment rates, that even countries that followed similar adjustment programs are nowadays demonstrating. The key problem however is that despite this induced intense fiscal adjustment the aim for low public debt to GDP ratio was never achieved; on the contrary even in absolute numbers public debt is still considerably rising, triggering a strong debate regarding its viability. This situation reveals that the of any kind designed 


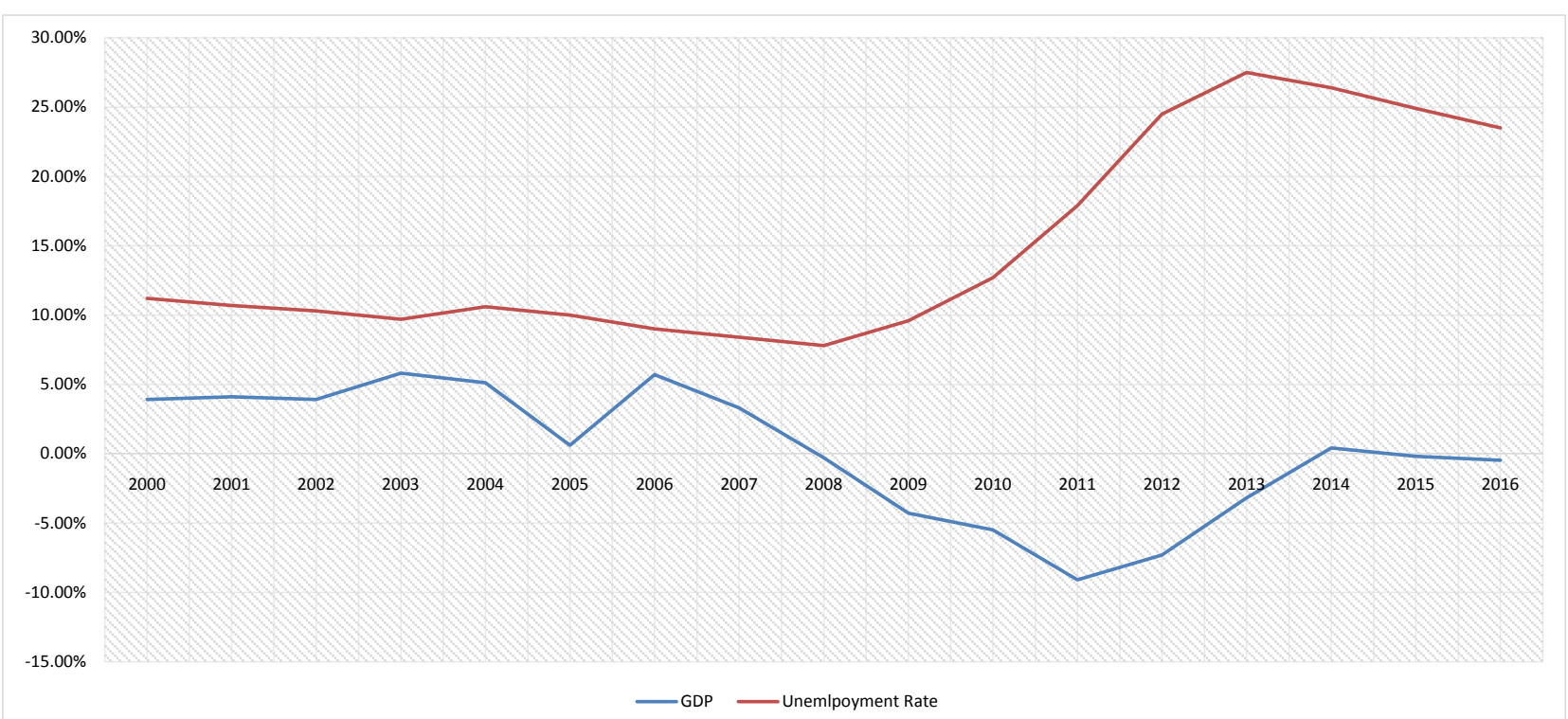

Figure 1. GDP and Unemployment Rate in Greece (annual change in \%). Source: AMECO Database; Own calculations.

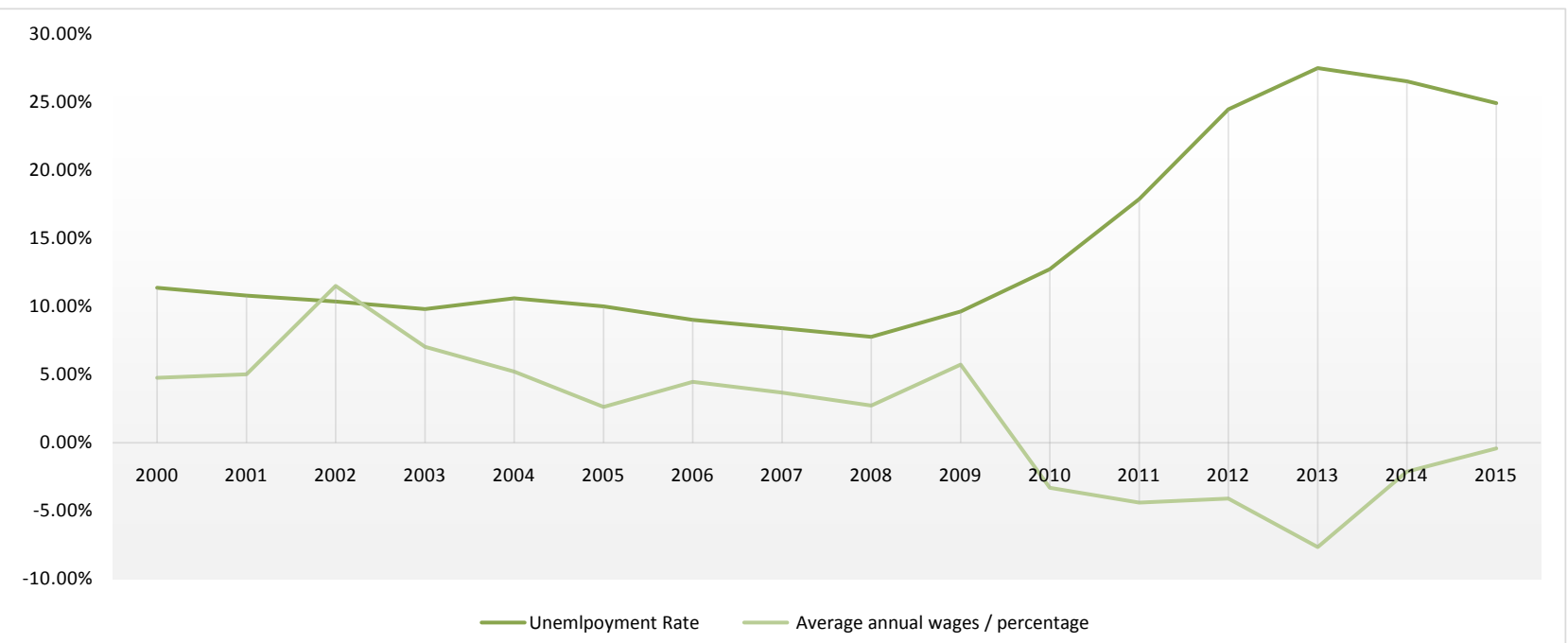

Figure 2. Unemlpoyment Rate and Average Annual Change of Wages in \%. Source: AMECO Database and OECD Data [17]; Own calculations.

counter-cycle growth dynamics never worked the way they were expected to, while recession multipliers were much higher than what was estimated in the adjustment programs. Subsequently, recession proved to be much more intense compared to savings and domestic demand downsizing, ending in putting economy in a vicious circle. Enormous austerity caused a collapse of to the actual buying power of the population. Many explanations have been provided by the scientific community for this development. Intense political turmoilis suggested to have played a key role in order for crucial decisions to be taken in a later time than what it was expected and obviously needed. Macroeconomic instabilities also seem to have a key role in order for institutions estimations to be 
derailed in reality, while the possibility of a "Grexit" carved an unfriendly and high risk investment environment, discouraging foreign capitals to invest in Greece, a trend enhanced by the really legarthic pace for privatizations. The slowly moving public sector and the obstacles it puts to investors due to its amazing legal framework and organization, didn't support the total effort. The combination of all of the above not only made difficult to succeed in growing GDP, but also intensified the already existing liquidity shortages.

This combination put Greek economy into a recessional vicious circle were cuts of public spending dominated, raises of direct and indirect taxation were noted, and wages and pension cuts caused immerse demand shrinkage, driving a near collapse of GDP. This in turn led to worsening of fiscal situation, forcing the government to take more austerity measures and so on [29]. The collapse of domestic demand, due to lower wages and pensions severely decreased the disposable incomes, which combined with the political and economic uncertainty, led to extreme increase of unemployment rate (Figure 3). This phenomenon was analyzed in a recent research [30], were it was indicated, based on historical facts, that in EU when wages are lowering, domestic demand also follows the same trend. In addition it was observed that in case domestic demand is dropping, unemployment rate is increasing, a set of observations fully confirmed in the Greek scenario.

Regarding the second medium term objective of the adjustment programs, namely to eliminate the negative external trade balance, we can observe that it is nearly achieved. In terms of absolute values the exports balance for 2016 is only marginally negative, reaching a $-0.35 \%$ with respect to the GDP (Figure 4 ).

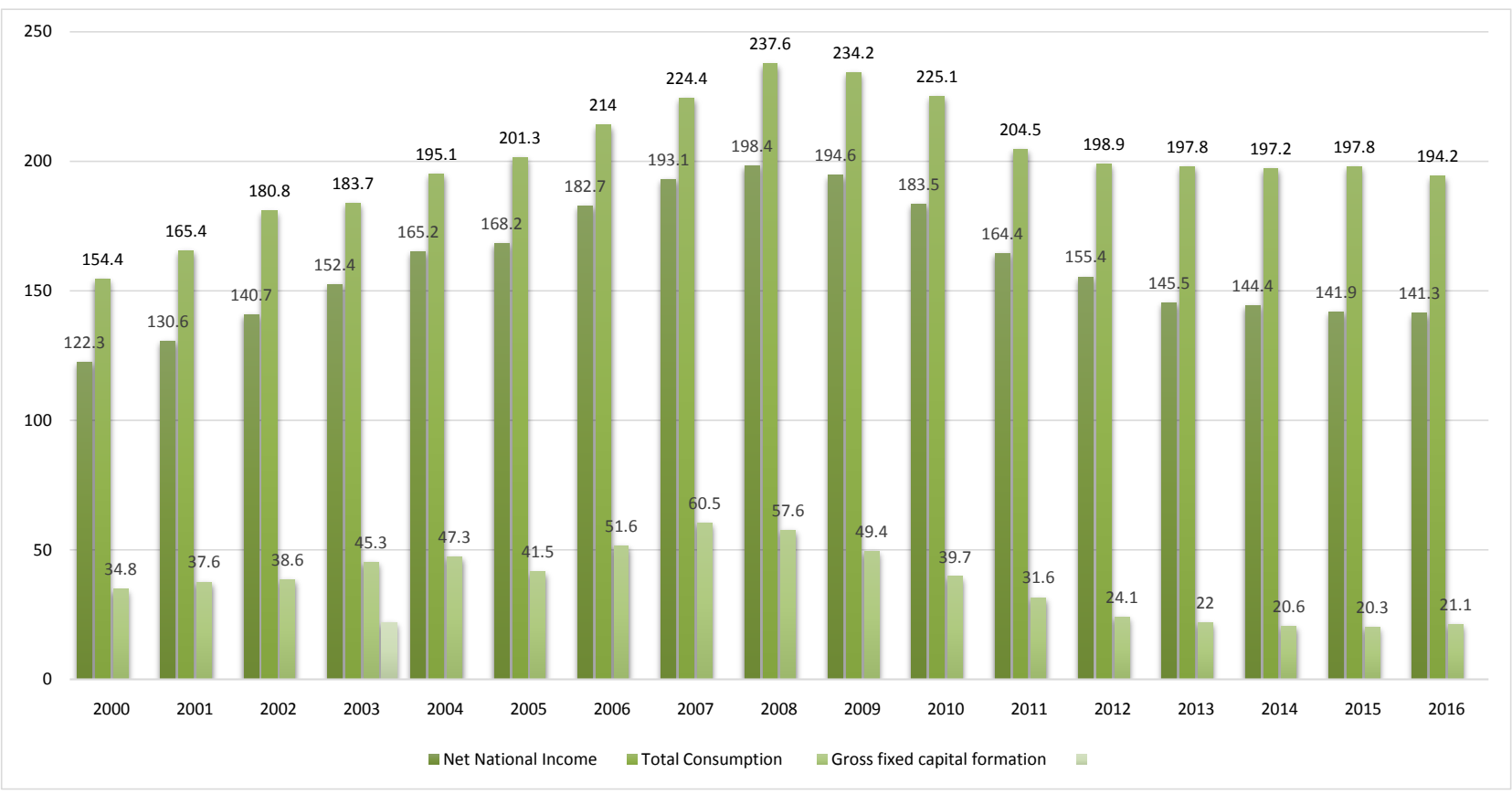

Figure 3. Net National Income, Total Consumption and Gross Fixed Capital Formation in Bil. Euros. Source: AMECO Database and OECD Data [17]; Own calculations. 


\section{EXPORTS - IMPORTS (\% OD GDP)}

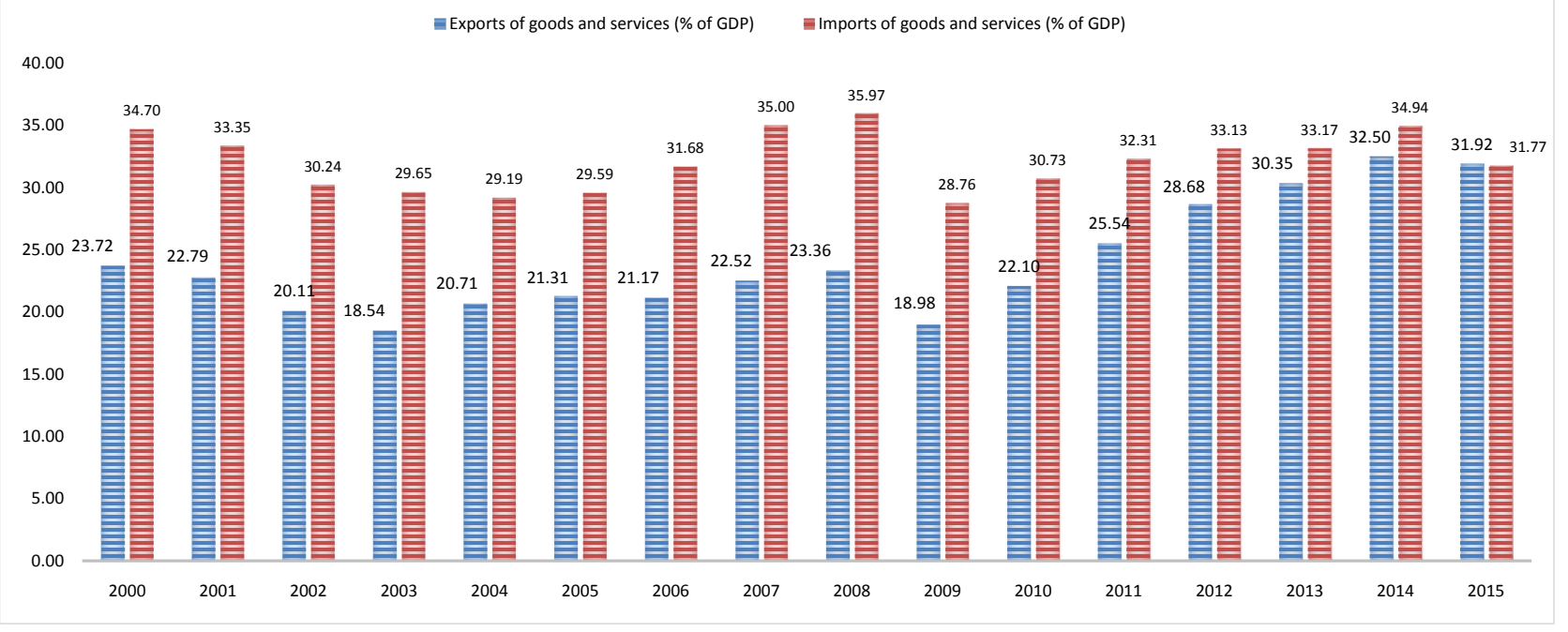

Figure 4. Exports-Imports (\% of GDP). Source: AMECO Database and OECD Data [17]; Own calculations.

However this elimination of external balance gap was mainly based on the radical lowering of imports, which can be imputed to the shrinkage of purchasing power of Greeks, and not due to the anticipated hefty raise of goods and services exporting, a fact that would have flagged the improvement of international Greek competitiveness (Figure 5). Thus, Greek households simply could afford less products and services, due to internal devaluation and recession (Figure 6) [31]. Also another worrying observation is the fact that Greek exporting performance didn't manage to follow international trends, indicating the foundational deficiencies of Greek economy competitiveness in terms of international trading, and in excess implied that the whole adjustment approach indeed decreased competitiveness rather than advancing it, as it was the case in other EU countries under adjustment programmes (Figure 7 and Figure 8) [32].

These alarming signals came to be confirmed by the World Economic Forum, Global Competitiveness Index and the rankings that Greece achieved for the period of interest. In more detail from 2006 till 2016 Greece lost 25 places in the Global Ranking, falling from the $61^{\text {st }}$ place to the $86^{\text {th }}$, in total of 134 countries. However we need to make a notice that its worst performance was during 2012, which fell to the $96^{\text {th }}$ position, making some steps of improvement hereafter (Figure 9). On top of that, the country performance in 10 out of 12 competitiveness pillars was worsening, with the worst performance to be observed in Financial Market Development, Macroeconomic Environment, Goods Market Efficiency, Institutions and mainly in Labour Market Efficiency (Figure 9 and Figure 10). One really worrying result is that regarding the "Effectiveness of Anti-monopoly", Greece lost 61 positions, providing another clear indication, with the combination of the aforementioned rankings this time that the applied adjustment policies mix, failed to enhance the Greek economy productivity and improve the characteristics of its production model, and thus missed its objectives. 


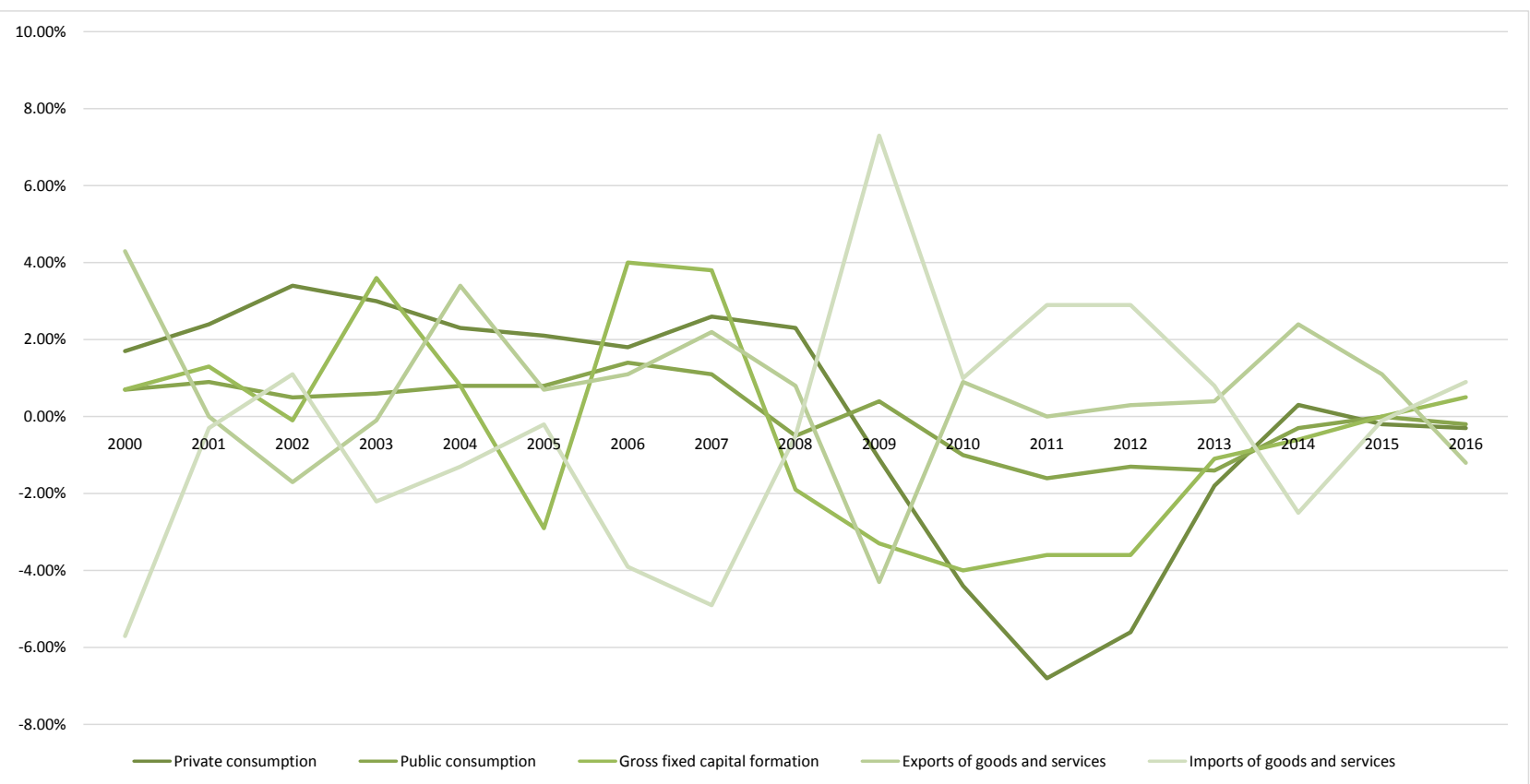

Figure 5. Contribution to the increase of GDP (constant prices). Source: AMECO Database and OECD Data [17]; Own calculations.

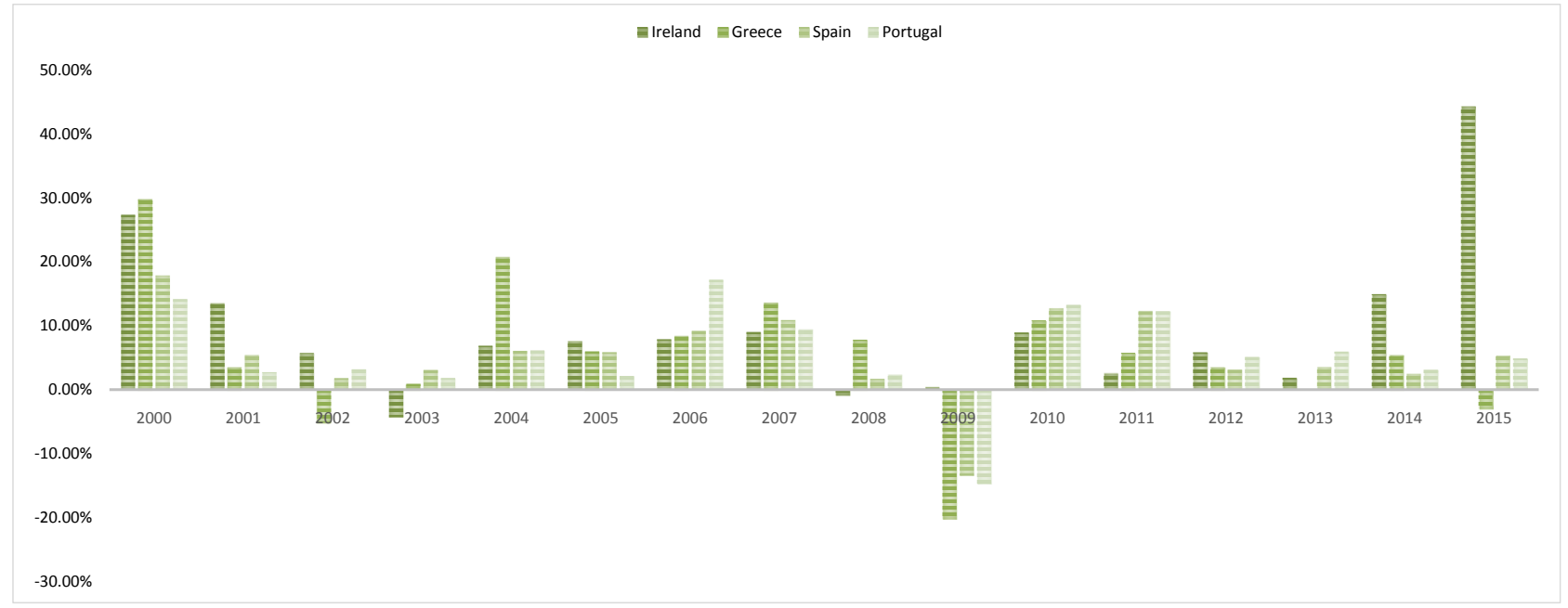

Figure 6. Exports of selected countries (annual change in \%). Source: AMECO Database and OECD Data [17]; Own calculations.

Even this neutralization of external trade balance, since it is achieved almost purely through internal devaluation and recession, makes it not sustainable; only if competitiveness of the Greek economy was significantly improved and the production model was radically altered such a sustainability aim could be made possible.

As analyzed in the following lines, structural weaknesses and drawbacks of the Greek economy and ineffectiveness of its production model are remaining intact, an observation that explains the failure of achieving the set objectives, and turn whichever improvements vulnerable and hardly sustainable. 


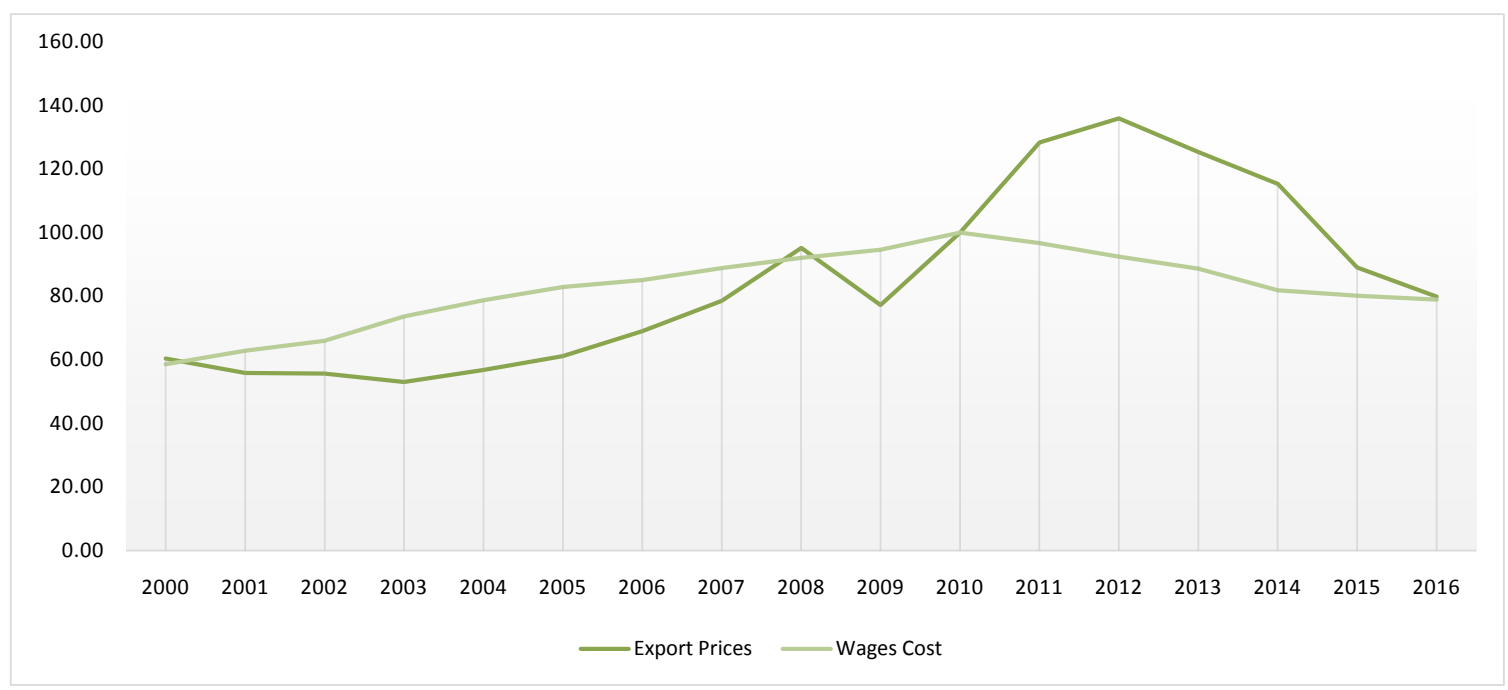

Figure 7. Development of Export Prices and Wage Cost $(2010=100)$. Source: AMECO Database and OECD Data [17]; Own calculations.

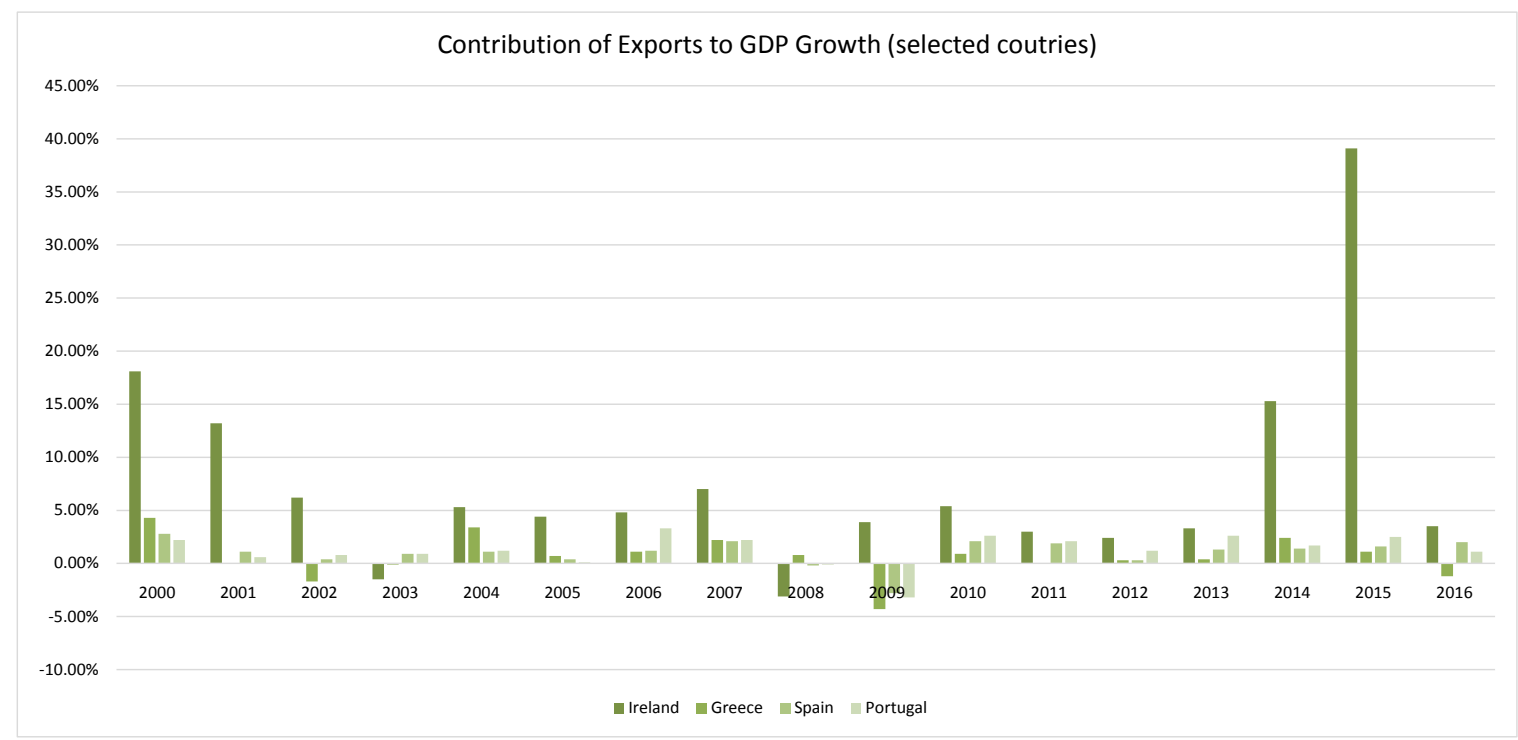

Figure 8. Contribution of Exports to GDP Growth (selected coutries). Source: AMECO Database and OECD Data [17]; Own calculations.

\section{The Role of the Greek Economy's Structural Weaknesses}

\subsection{The Predominance of Consumption against Savings and Investment}

Greece, from the middle of the 90s, experienced a rapid increase of GDP, a trend maintained and after its accession in the Euro zone (Figure 2). This was fuelled mainly by the domestic consumption and in much lesser portion by exports, a tendency enhanced by the capacity for borrowing from abroad with very low interest rates, combined with EU subsidies [18]. On the contrary, savings and investments were constantly waning with respect of the GDP (Figure 11). After the year 2010 and the ignition of the adjustment programmes consumption was 


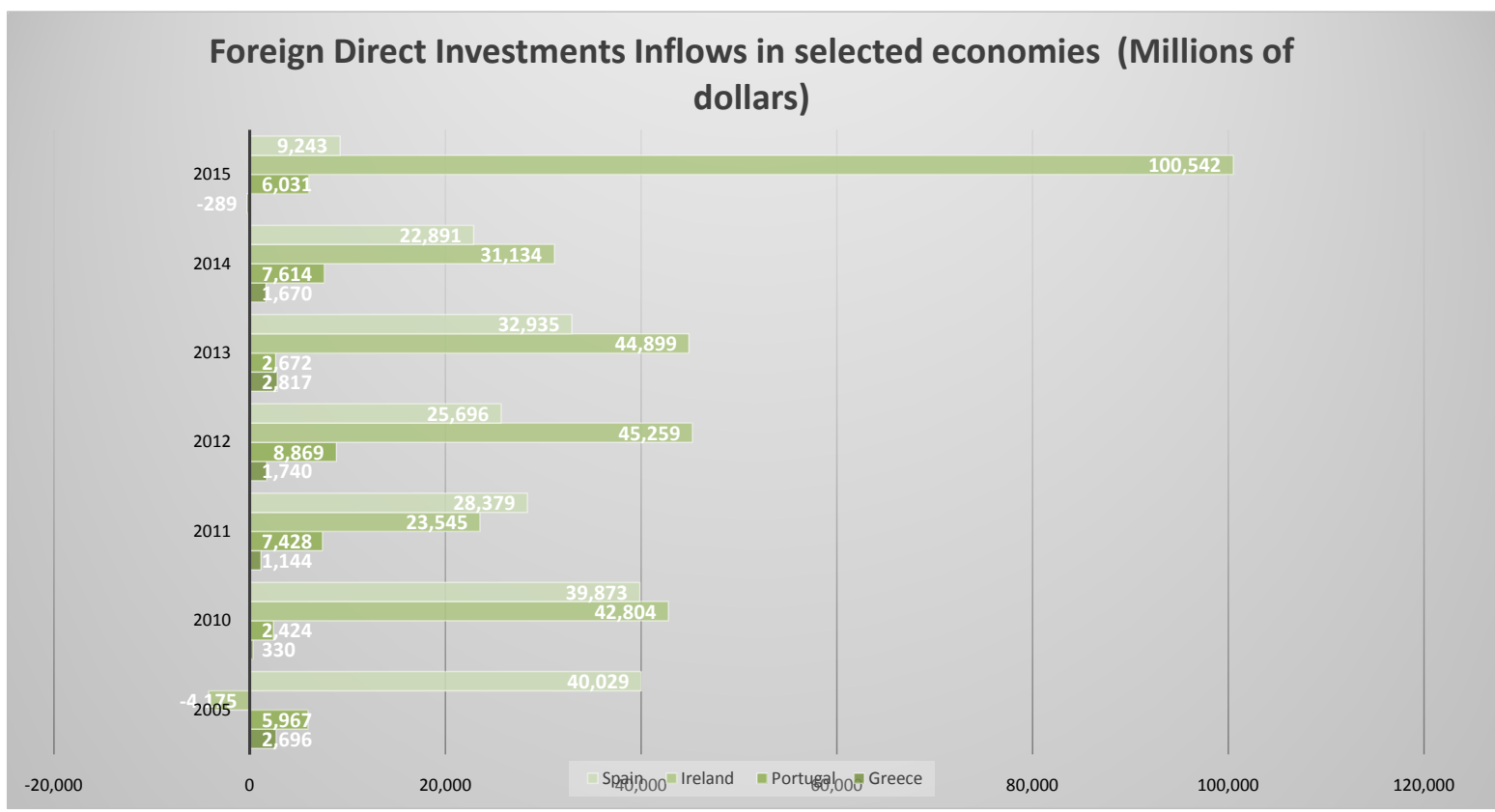

Figure 9. Foreign Direct Investments Inflows in Selected Economies (Millions of dollars). Source: UNCTAD; Own calculations.

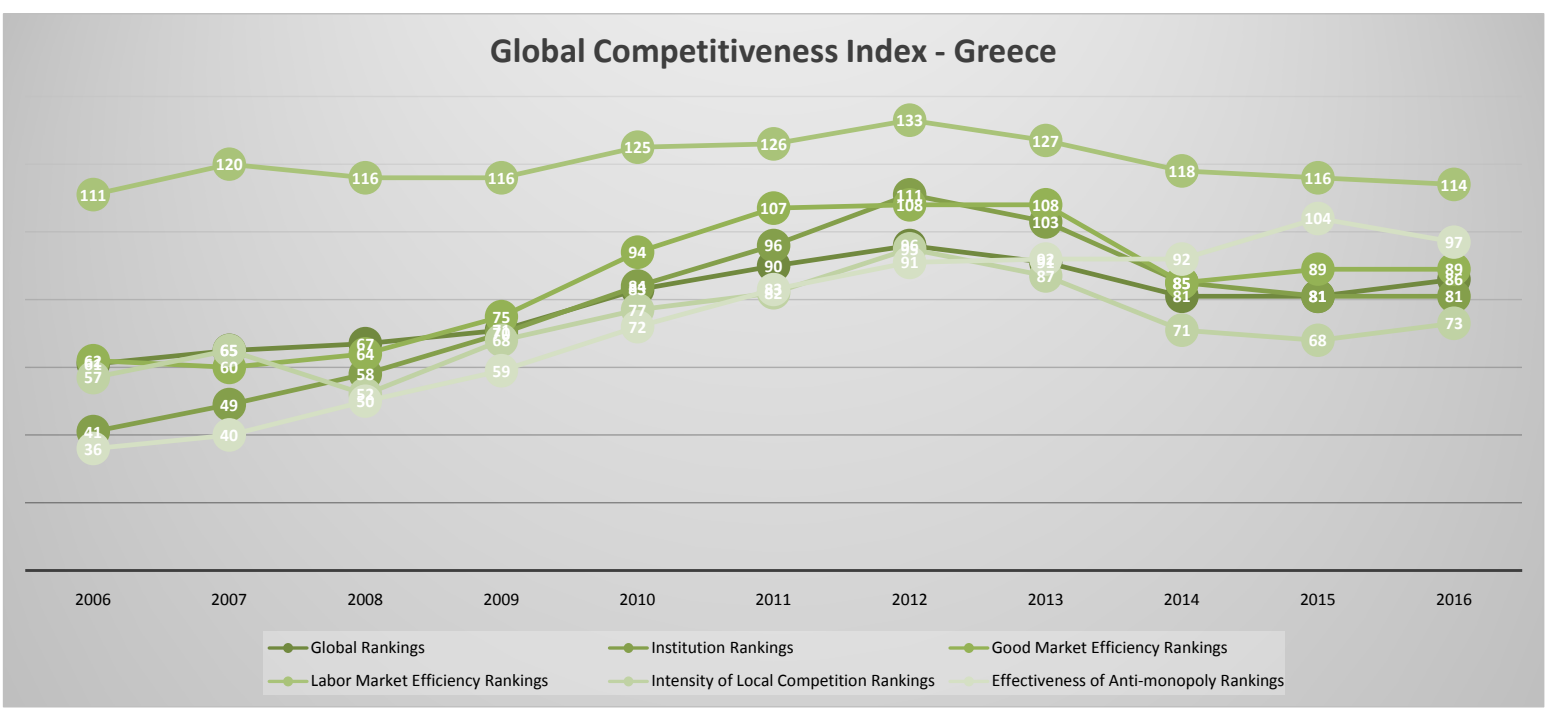

Figure 10. Global Competitiveness Index-Greece. Source: World Economic Forum [35]; Own calculations.

not possible to be maintained at the same levels. Internal devaluation, high tax rates, liquidity limitations indeed crumbled domestic consumption, leading in a sharp fall of the GDP. The demand driven development model of the country was suddenly terminated. The approach promoted by the adjustment programs was to switch from this outdated and indeed highly inefficient model, to a new one, production driven this time, by shifting resources from consumption to production. However this did not work in the Greek case. On the contrary, consumption insisted in remaining a huge portion of the Greek GDP, and as a result its constant shrinkage, resulted in dragging down GDP. On top of that, savings 


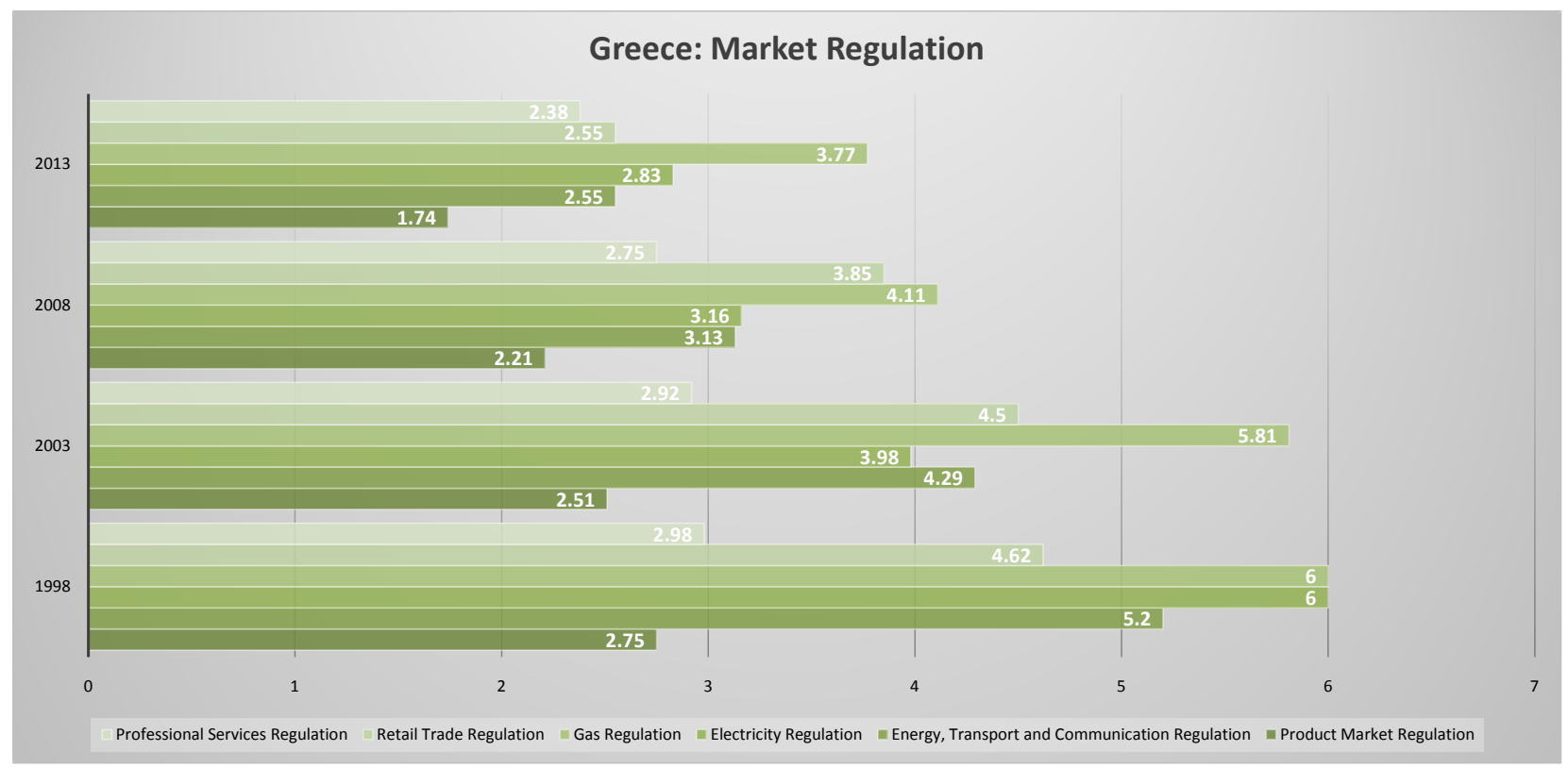

Figure 11. Greece: Market Regulation (0 - 6). Source: OECD [17]; Own calculations.

and investments were still condemned to be a small portion of GDP [6]. It is easy to link now, the fact that consumption as the main determinant for GDP, due its shrinkage was the main driver for the impressive decrease of imports. As a conclusion, recession effects were the main reasons for improving external trade balance, and subsequently not the desirable substation of imported goods from domestic ones. Investments to GDP ratio remained more or less unchained, and unfortunately so did Greek economic and productivity model.

As mentioned before, the development model of Greek economy heavily relied on borrowing from abroad, while due to the participation of Greece in the Eurozone, gave it access to capital with extremely low interest rates. This easily explains the boosting support of Greek economy provided through loans and mortgages, combined with high monetary liquidity. But in the framework of the adjustment programmes all of the above were overturned. Since 2010 the available amount of money was decreased by $36 \%$ and total bank credit at $30 \%$ [33]. This crumbled domestic consumption, in turn induced the high unemployment rates, due to the extreme introverted characteristics of the Greek economy. In order to complete the whole negative schematic, political turmoil and the frequent governmental changes, combined with conflicts between Greek government and country's creditors, intensified the drop in deposits, increased capital flight, aggravated bank problems and further increased the already high interest rates. This situation resulted to bank run, and capital flee abroad, culminating of this process and leading to obligatory bank holidays and capital controls, adding even more restrictions to consumption. Businesses also had to face now additional liquidity stagnation and crediting shortages, leading to an almost complete halt in the crucial crediting role of banking sector. That worked as a tombstone in the efforts of refinancing economy and recovery of its robustness. 
Banking sector ended up in its very own vicious circle, since the reduction of liquidity that caused the domestic consumption driven recession, induced a shortened loan servicing, added up with capital flight, thus further worsening liquidity conditions and refeeding recession.

Greek economy, for a long time now heavily relies in using EU funds in order to co-finance its development plans and provide valuable resources to many crucial projects. However the shrinkage of public sector investments and spending, together with the misfire and the inefficient usage of the Structural Funds, added up to the whole recessional environment.

\subsection{The Greek Economy's Introversion and Low Output Elasticity}

All restructuring programmes designed and implemented during the economic crisis in European continent had the primary objective of increasing international competitiveness of troubled countries' economies. The main chosen tool for succeeding this objective in Euro countries was the internal devaluation adopting a twofold aiming. The first was to enhance exporting trade through increasing competitiveness due to lower production costs, and the second was to decrease imports due to lower purchasing power for imported goods and in parallel enhance demand for the domestic production which subsequently should be able to offer lower prices. This strategy seems well established and appears to have been effective to all troubled Euro countries but Greece.

The reason that this approach failed to work in Greece lies deeply inside these very unique characteristics of Greek economy, its structure and character. Greek economy is characterised by strong introversion and week secondary sector. The latter represents only a small portion of Greek economy, even though in modern economies it is usual to be the most influential sector for promoting international trade. On the contrary, primary production is heavily headed towards domestic consumption. Most active sectors in the Greek case are characterized by low international competitiveness and/or exporting potential, while in addition most Greek companies can generally demonstrate little participation in international trading networks and clusters.

The internal structure of the Greek economy is symbolized by the large number of small enterprises, self-employed and freelancers, demonstrating low production capacity and overall external trade orientation. 30\% (AMECO) of Greek enterprises employ one to nine employers, putting Greece in the first rank on this indicator. Unfortunately, such enterprises do not have the experience, the structure, the resources and the required capacity in order to shift their activities towards external markets. Their major targeting was and remains the domestic one. The absence of any coherent policies for supporting the establishment of networks, clusters and capacity building enhancement, left such enterprises struggling on their own to cope with the increasing intensity of the domestic market shrinkage and all the others crises induced difficulties.

To make things even worst, the deep cut in lending capital that was observed 
from the very begging of the crises turned every attempt to shift towards international markets even more difficult and challenging. And if mining capital for medium and big companies was hard, for small and very small companies this was extremely harsh, since the banking system reservations were extremely intense and the collaterals required turned the stakes in extreme heights for them.

The deduction of the salary levels did not initiate a proportionate drop of the Greek production costs, and subsequently products and services prices, as it was anticipated (Figure 12). This turned even, due to other costs that rose for businesses in the same period that consumed this created margin, while some enterprises chose to raise their profit margins. Increased taxation for business and self-employed, and the higher costs due to capital risks indeed vanished a great portion of the potential gain from the lower labour costs.

The Greek economy structure and its geographical centralization do not support its dynamic exporting growth, with the notable exclusion however of the shipping and tourism industries. Still a great volume of the Greek external trade is headed towards countries with domestic markets of weaker dynamics.

As a result of all the aforementioned, no notable exports increase was observed, a desirable outcome that could have supported the economic recovery, as it happened in other Eurozone countries. On the contrary what we really observed was the intense decline of imports, which represents the domestic loss of purchasing power and reluctance in spending, due to uncertainty (Figure 13) [34].

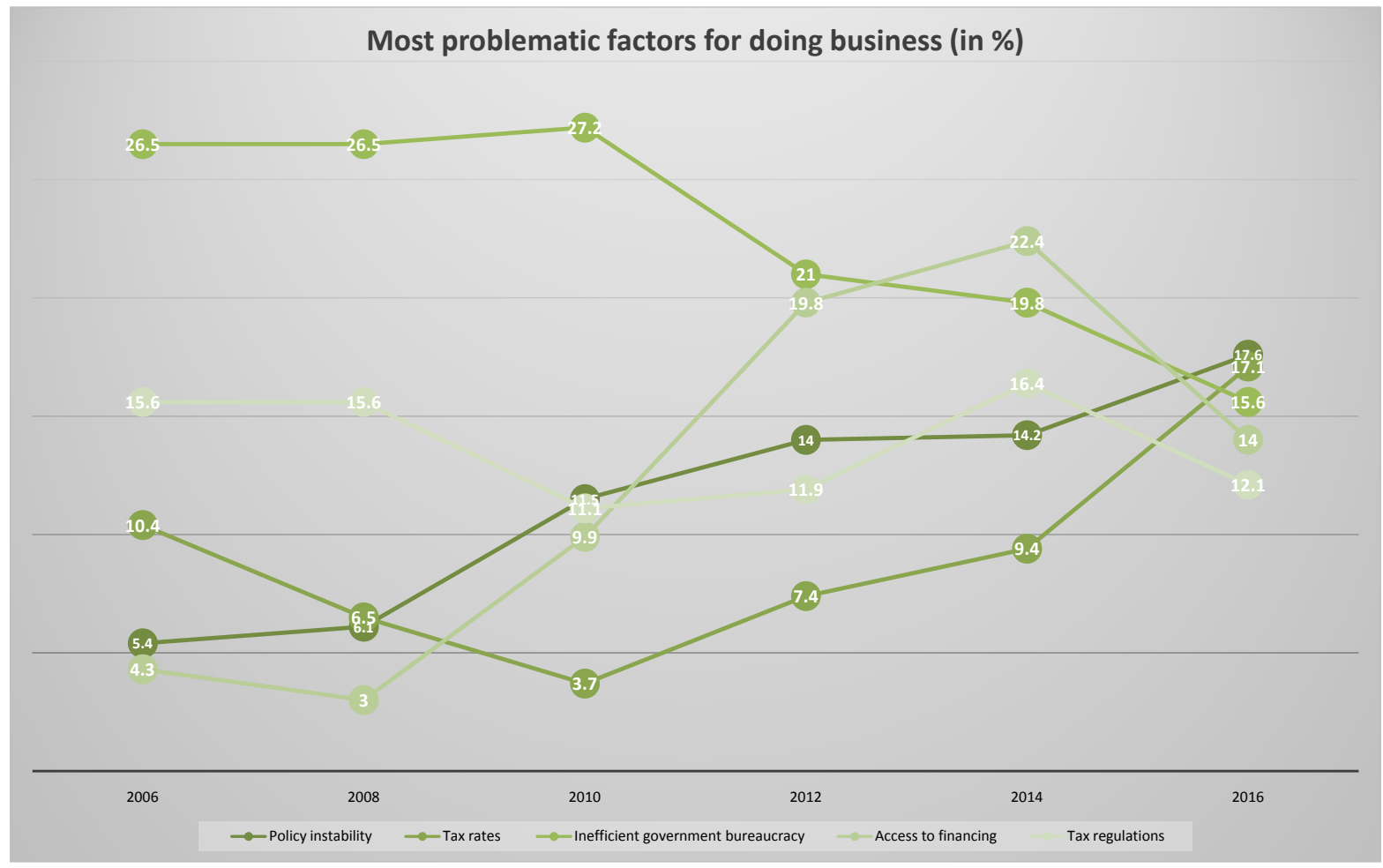

Figure 12. Most problematic factors for doing business (in \% survey's responses). Source: World Economic Forum [35]; Own calculations. 


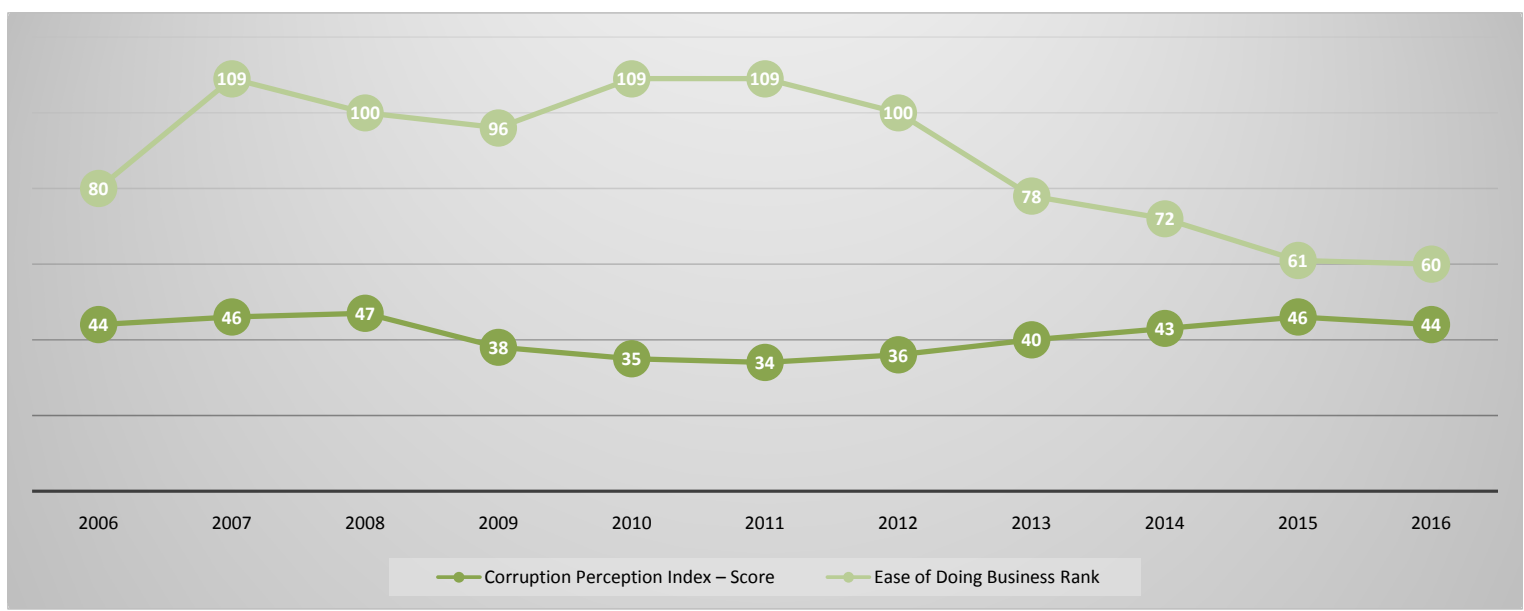

Figure 13. Doing Business and Corruption Indices. Source: World Bank; Transparency International [34]; Own calculations.

\subsection{Systemic Factors of Greece's Low International Investment Competitiveness}

Greece was never, even in the past decades of strong economic growth, a really attractive destination for foreign direct investments. Even before the crisis outbreak, investments attracted by foreign capital were much lower compared to the other EU countries. In the period between 2004 and 2010, direct foreign investments represented a mean of $3.7 \%$ of the GDP for EU countries, while for Greece this figure was as low as $1 \%$. For comparison reasons we mention that other South-Eastern countries could demonstrate a figure of $2 \%$. By observing Figure 14 we can clearly indicate that Greece was unable to attract foreign capitals even compared with other countries that went through similar recovery programmes, a finding that reveals the intrinsic unattractiveness of Greek economy.

So another field for discussion is to identify these factors that were repelling foreign investors before 2009 and estimate if the reform programmes managed to militate them. In addition, we need to examine if the turmoil of the economic crisis gave rise to new obstacles and how these are evolving through time.

Going through the reports that the World Economic Forum [35], the OECD and the World Bank annually publish and display in a comparative approach the characteristics of national economies around the globe, we can shape a number of observations that shed light to the Greek economy current conditions. According to the World Economic Forum [35], Global Competitiveness Report of 2016, the total competitiveness index for Greece is declining since 2004. A slight recovery was observed for the period between 2012 till 2015, only to get worst after that period once again (Figure 9 and Figure 10). In most partial factors that WEF examines, the situation is similar. One really worrying finding however is the more or less unchained Labor Market Efficiency Rankings of Greece which remain extremely low regardless of the rapid decline of wages, giving an additional indication that labor cost is not the main issue for Greek productivity. 
Public pension Spending and Budget Subsidies

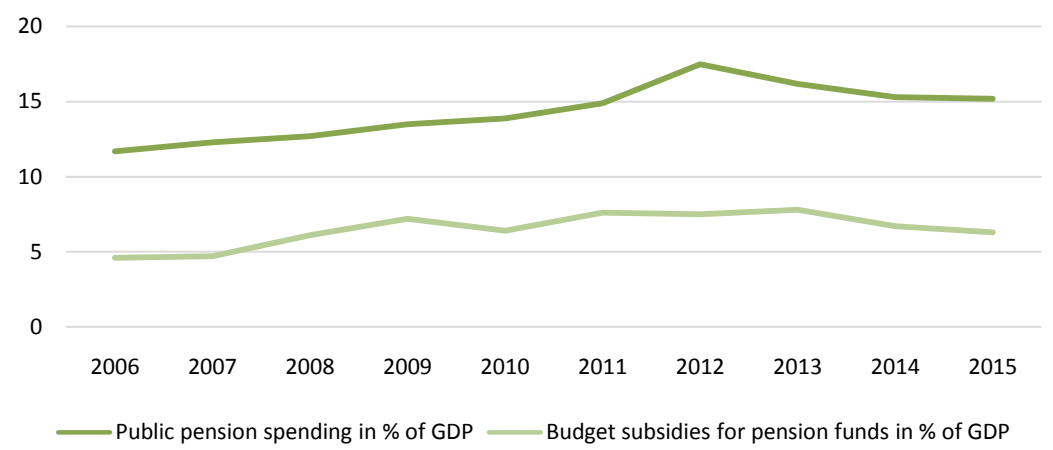

Figure 14. Public pension Spending and Budget Subsidies (in \% of GDP). Source: Eurostat; Hellenic Ministry of Finance; Own calculations.

Another interesting finding is the crumbling of effectiveness of anti-monopoly policies, a direct indication that competitiveness fundamentals are not properly applied in the country. Even though open competition barriers are lowering for the last 20 years, still a lot need to be done; increased concentration, or excessively regulatory framework, and ineffectiveness of antimonopoly policies, make Greece lacking the proper open competition environment, especially compared with other EU countries.

It is therefore interesting to spot the most discouraging factors for foreigners to doing business in Greece (Figure 15). According to the World Economic Forum [35], Executive Opinion Survey for 2016, inefficient government bureaucracy was historically the most troubling factor for doing business in Greece, even though, the situation seems to have greatly improved from 2012 and on. Complex tax regulation is another main issue, while the high level of taxation is coming again to the surface. The two modern problems however are those of the difficulty in accessing financing and the policy instability. These two seem to be the results of the economic crisis, since they have never bothered foreign executives before.

On the other hand, one encouraging finding is the ease of doing business ranking, which since 2011 and on demonstrates a notable improvement [36] (Figure 13). However the corruption perception index returned to the levels that it stood one decade before, losing the slight improvement ratio it gained, in the late 00s. It is important to underline that this positive trend was interrupted during the years of the crisis, a sound failure of the adjustment programs.

Keeping in mind the aforementioned factors, we can summarize that in total, Greece failed to dramatically bowl over the causes that made the country an unfavorable destination for foreign direct investments. On the contrary many critical parameters turned worst while new risks and problems aroused. This combination worsened the whole picture, and deprived Greece from a countermeasure to the incapability of crediting and deriving domestic liquidity for investments, through attracting massive foreign direct investments. Greece failed 


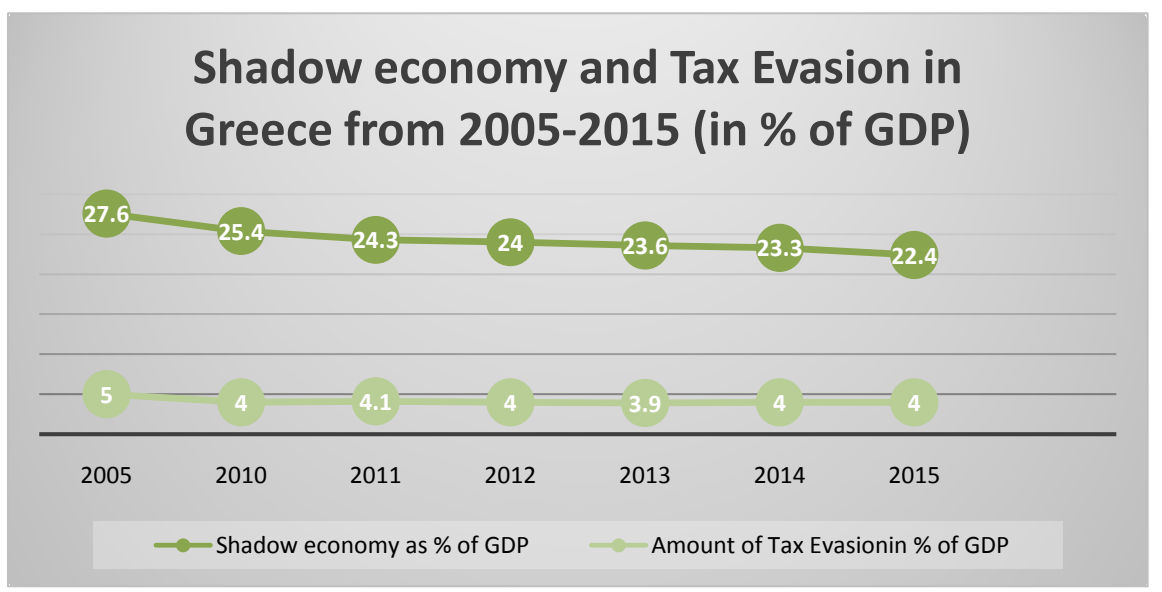

Figure 15. Shadow economy and Tax Evasion in Greece from 2005-2015 (in \% of GDP). Source: Schneider [41]; Artavanis et al. [42]; Ernst \& Young [35]; Own calculations.

to mimic the other countries under adjustment programs on this field. Internal characteristics seem to establish immense obstacles, thus turning Greece to a less favorable destination for foreign investors compared to other countries in adjustment programs.

\subsection{The Chronic Structural Weaknesses of Public Finances}

The derailment of Greece's public finances and the debt crisis are symptoms of a malaise of the Greek political and economic system, the fiscal causes of which run even deeper. First of all, the political system has an inherent tendency to cave in to vested interests, such as labour unions, state-owned enterprises, state-subsidy-dependent private enterprises, as well as other social groups [16]. Then, there are the chronic problems regarding the organisation and operation of the tax collection mechanism, as well as of enforcement of tax law [37]. As mentioned above, over-regulation and the complexity of tax law, in conjunction with high tax rates, is another reason behind limited tax collection. From 1975 to 2016, for example, more than 250 tax bills were passed by Parliament and almost 115,000 tax-related ministerial decisions were issued, which not only failed to improve the country's tax system but, on the contrary, rendered it even more opaque, ineffective, and costly to administer [38]. Following the advent of the crisis and the subsequent deepening of the recession, the problem was compounded by the state's failure to collect verified direct and indirect taxes [38]. However, the build-up of the public debt was mostly due to two deeper causes, which are related with excessive spending and the loss of revenues and were targeted by adjustment policy from the very outset. So, the question is whether these causes were effectively dealt with.

The first cause, which constitutes a chronic deficiency of Greece's public finances, is the high expenditure on social security and, in particular, pensions [37]. Owing to a series of problems that plague the social security system, such as contribution evasion, undeclared work, unemployment, the comparatively large 
number of pensioners and, above all, the high replacement ratio, i.e. the percentage of the workers' earnings that is paid in the form of a pension after retirement, where Greece was ranked 1st among EU member states in 2009, Greek pension funds have been traditionally running deficits, which are funded by the government budget [39]. This led to the significant increase of total public expenditure on pensions (pensions paid to government employees and subsidies paid to pension funds), as shown in Figure 14. However, the greatest problem of Greece's social security system is the funding of pension fund deficits through state subsidies [37]. In 2000, this subsidy stood at 4.8 billion Euro (3.3\% of GDP), while in 2009 it rose to 17 billion Euro (7.2\% of GDP), becoming a permanent cause of budget deficits and public debt accumulation.

In the ten-years 2000-2009, pension funds were subsidised by the government budget with 98 billion Euro, an amount that accounts for $61 \%$ of the increase in public debt during the same period, turning the pension issue into the primary cause of the 2009/10 crisis. In the 15-years 2000-2016, the subsidies paid to pension funds amounted to 191 billion Euro, i.e. $58 \%$ of the existing public debt (at the end of 2016). After the launching of the adjustment programmes there was an effort to reduce the total pension spending that, nonetheless, remains very high in comparison to other OECD countries [37]. Thus, in 2014 total spending on pensions accounted for $15.3 \%$ of the Greek GDP, when the OECD country average stood at $7.9 \%$ of GDP. The annual state subsidy paid to Greek pension funds also remains very high. Despite a slight reduction in 2013, the 2017 the government budget provides for an increase in state subsidies equal to $8.8 \%$ of GDP.

High public spending on pensions does not only impose a burden on the government budget, making it difficult to finance the deficits and service the debt. It also has major growth effects, as it distorts the distribution of resources in favour of consumption, and against investment and economic growth. Moreover, by incessantly increasing social security contributions and taxes, in order to finance pension fund deficits, the government reduces the workers' disposable incomes and, consequently, their demand, savings, and willingness to work, enhancing, at the same time, the informal economy, contribution and tax evasion, and the emigration of young people. Therefore, a radical pension system reform is a main prerequisite for the country's exit from the recessionary vicious circle [37] [40] [41] [42].

The second deep-rooted cause of government over-indebtedness is related to the shadow economy and tax evasion [43]. Cracking down on tax evasion has been a stated goal of every Greek government and one of the key aims of adjustment policy. Tax evasion does not only cause revenue loss for the government and the pension funds. Economic sectors that offer lots of potential for tax evasion, such as freelance professions and small and medium-sized enterprises, especially in the consumer services industry, are continuously attracting economic resources, thus reducing the economy's capacity and enhancing its introversion [38]. Moreover, tax evasion creates an uneven playing field, given that 
tax evaders enjoy a competitive advantage in regard to the final cost and the price of their goods and services. This may possibly give rise to imitative behaviours, as the businesses that pay their taxes are threatened with being driven out of the market.

The full measurement of the gray economy and tax evasion is an almost impossible task. For this reason, all relevant studies stress that they constitute an approximation, and not an exact representation, of the phenomenon [44] [45]. Figure 15 shows the development of the gray economy and tax evasion in Greece before and after the crisis. We can see that these phenomena were slightly contained after 2010. Compared with the other EU countries, however, Greece remains in the group of countries with the largest gray economies and the highest tax evasion rates. According to a recent survey [38], tax evasion (2015) is estimated at 6\% - 9\% of GDP and leads to an annual state revenue loss of 16 billion Euro. This lost revenue would be enough to cover the public sector's payroll cost (15 billion) or overbalance the annual debt servicing requirements. As a result of the above, the efforts to increase government and pension fund revenues, impose an excessive burden on those businesses and workers that are unable to under-report their incomes. This, in conjunction with the recession, leads to the continuous growth of overdue obligations to the state.

According to the relevant studies [37] [38] [43] [44] [45], Greece's shadow economy and high tax evasion are due to a very wide range of factors, related to over-regulation and the complexity of the tax system; legal uncertainty; high tax rates; the lack of political will for dealing with this phenomenon; the insufficient technical and organisational infrastructure of the tax administration; bureaucracy; the extremely large number of self-employed individuals and very small enterprises; and cultural factors, such as the citizens' attitude towards the state and tax morale.

Based on the above, it is easy to conclude that, despite any efforts, tax evasion has not been dealt with and, therefore, the solution of Greece's fiscal problem requires the implementation of a coherent strategy, emphasising on measures aimed at remedying the causes, such as: the reduction of tax rates; the use of plastic money and electronic invoicing; the tightening of tax audits and the establishment of harsher penalties; the upgrading of the technology and the streamlining of the operation of the tax authorities; the proper staffing of the tax authorities; the creation of a stable and simplified tax system, the enhancement of tax conscience, and the change of the country's productive model.

\section{Regression Analysis}

\subsection{Data, Variables and Methodology}

\subsubsection{Data}

Our dataset consists of nineteen countries of the European Union (Austria, Belgium, Czech Republic, Denmark, Estonia, France, Germany, Greece, Hungary, Ireland, Italy, Latvia, Netherlands, Poland, Portugal, Slovak Republic, Slovenia, 
Spain, and the UK) and Turkey. The relevant country figures are for the period 2000-2015 and come from OECD, the World Bank and the United Nations Conference on Trade and Development [46].

\subsubsection{Variables}

The variables that are used as measures of structural weaknesses or strengths of an economy - and are the independent variables in our model-are the competitiveness index, the labor cost, the political stability, the corporate income tax rate, the ease of doing business, the corruption, the labor unions (the number), the pensioners (as a percent), the unemployment (as a percent), the pensions (as a percent of GDP), the profit tax rate and the public debt (as a percent of GDP). We use investments/GDP, gross fixed capital formation, the FDI inflows, the GDP growth, the GDP per capita, the GDP, the CPI (consumer price index), the consumption, the unemployment, the public debt, the imports and the exports as determinants of the effectiveness of an adjustment program. These are the dependent variables of our model. We use the averages for the years 2000-2015 of the above variables, so as to have an indication of the trend (Table 1).

\subsubsection{Methodology}

We attempt the use of linear regression in order to link the measures of the structural weakness or strength of a country with the determinants of the effectiveness of an adjustment program. As mentioned in the previous paragraph (Variables), the measures of structural weakness or country are captured by the independent variables and the determinants of the success of an adjustment program are captured by the dependent variables. The regressions we run use one dependent and one independent variable. The general form of the regression equation is:

Table 1. Variables.

\begin{tabular}{cc}
\hline DependentVariables & IndependentVariables \\
\hline Investments/GDP & Competitivenessindex \\
Grossfixedcapitalformation & Laborcost \\
FDI inflows & Politicalstabilty \\
GDP growth & Corporateincometaxrate \\
GDP per capita & Ease of doingbusiness \\
GDP & Corruption \\
CPI (consumerpriceindex) & Laborunions (number) \\
Consumption & Pensioners (percent) \\
Unemployment (percent) & Unemployment (percent) \\
Public debt (as a \% of GDP) & Pensionsas \% of GDP \\
Imports & Profittax (rate) \\
Exports & Public debt (as a \% of GDP)
\end{tabular}




$$
E A P=\beta_{0}+\beta_{1} \cdot S W+u
$$

where $S W$ (structural weaknesses) is any of the above variables that reflect the structural weakness or strength and $E A P$ (effectiveness of adjustment program) is any of the variables that determine the success of an adjustment program. $\beta_{1}$ denotes the coefficient, $\beta_{0}$ denotes the constant term and $u$ denotes the stochastic error term. We use the Stata econometric software to run these linear regressions with Ordinary Least Squares (OLS). We use White's test to detect potential heteroskedasticity and we use Robust Standard Errors to tackle it when present.

\subsection{Regressions}

We regressed each of the independent variables with each of the dependent variables that as shown in the following tables and explained in the results section below (Table 2).

Table 2. Regressions summary Europe.

(a)

\begin{tabular}{|c|c|c|c|c|c|c|c|c|c|c|c|c|}
\hline $\begin{array}{l}\text { Variables/ } \\
\text { Regressions }\end{array}$ & (1) & (2) & (3) & $(4)$ & (5) & (6) & (7) & (8) & (9) & $(10)$ & (11) & (12) \\
\hline \multicolumn{13}{|l|}{$\begin{array}{l}\text { Dependent } \\
\text { Variables }\end{array}$} \\
\hline Investments/GDP & $\mathrm{X}$ & $\mathrm{X}$ & $\mathrm{X}$ & $\mathrm{X}$ & $\mathrm{X}$ & $\mathrm{X}$ & $\mathrm{X}$ & $\mathrm{X}$ & $\mathrm{X}$ & $\mathrm{X}$ & $\mathrm{X}$ & $\mathrm{X}$ \\
\hline \multicolumn{13}{|l|}{$\begin{array}{c}\text { Independent } \\
\text { Variables }\end{array}$} \\
\hline $\begin{array}{l}\text { Competitiveness } \\
\text { index }\end{array}$ & 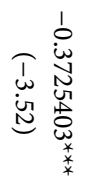 & & & & & & & & & & & \\
\hline Labor cost & & 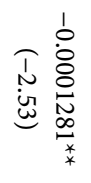 & & & & & & & & & & \\
\hline $\begin{array}{l}\text { Political } \\
\text { stability }\end{array}$ & & & 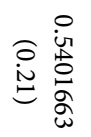 & & & & & & & & & \\
\hline $\begin{array}{l}\text { Corporate income } \\
\text { tax rate }\end{array}$ & & & & 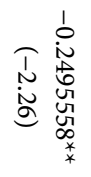 & & & & & & & & \\
\hline $\begin{array}{l}\text { Ease of doing } \\
\text { business }\end{array}$ & & & & & 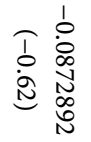 & & & & & & & \\
\hline
\end{tabular}




\section{Continued}

Corruption

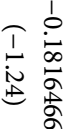

Labor unions

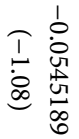

Pensioners

Oे

Unemployment

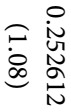

Pensions as \% of

GDP

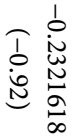

Profit tax

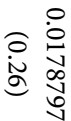

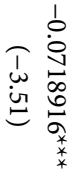

Public debt

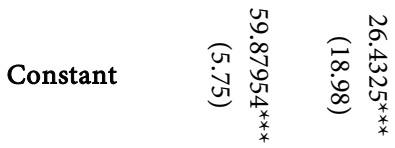

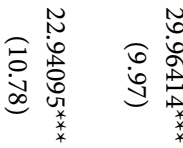

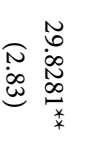

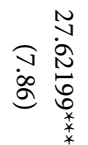

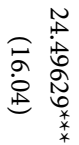

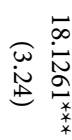

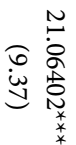

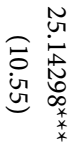

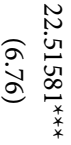

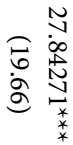

$\begin{array}{ccccccccccccc}\text { Observations } & 19 & 19 & 19 & 19 & 19 & 19 & 18 & 19 & 19 & 18 & 19 & 19 \\ \begin{array}{c}\text { Adjusted } \\ \text { R-squared }\end{array} & 0.3871 & 0.2311 & -0.0562 & 0.1864 & -0.0357 & 0.0296 & 0.0098 & -0.0062 & 0.0094 & -0.0089 & -0.0547 & 0.3857\end{array}$

Notes: t-values in parenthesis; ${ }^{* *}$ statistically significant at the $1 \%$ level; ${ }^{* *}$ statistically significant at the $5 \%$ level; ${ }^{*}$ statistically significant at the $10 \%$ level.

(b)

\begin{tabular}{|c|c|c|c|c|c|c|c|c|c|c|c|c|}
\hline $\begin{array}{l}\text { Variables/ } \\
\text { Regressions }\end{array}$ & (13) & (14) & (15) & (16) & (17) & (18) & (19) & (20) & (21) & (22) & (23) & (24) \\
\hline \multicolumn{13}{|l|}{$\begin{array}{l}\text { Dependent } \\
\text { Variables }\end{array}$} \\
\hline $\begin{array}{c}\text { Gross Fixed } \\
\text { Capital Formation }\end{array}$ & $X$ & $\mathrm{X}$ & $X$ & $\mathrm{X}$ & $\mathrm{X}$ & $\mathrm{X}$ & $\mathrm{X}$ & $\mathrm{X}$ & $\mathrm{X}$ & $\mathrm{X}$ & $\mathrm{X}$ & $\mathrm{X}$ \\
\hline \multicolumn{13}{|l|}{$\begin{array}{l}\text { Independent } \\
\text { Variables }\end{array}$} \\
\hline $\begin{array}{l}\text { Competitiveness } \\
\text { index }\end{array}$ & 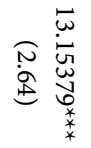 & & & & & & & & & & & \\
\hline
\end{tabular}




\section{Continued}

Labor cost

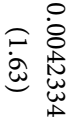

Political stability

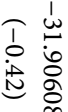

\begin{tabular}{|c|c|}
\hline Corporate income & \\
\hline tax rate & $\stackrel{\sim}{0}$ \\
\hline
\end{tabular}

Ease of doing

business

Corruption

Labor unions

Pensioners

Unemployment

Pensions as \% of

GDP

Profit tax

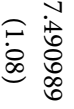

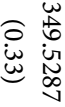

莣空

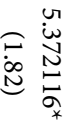

Public debt

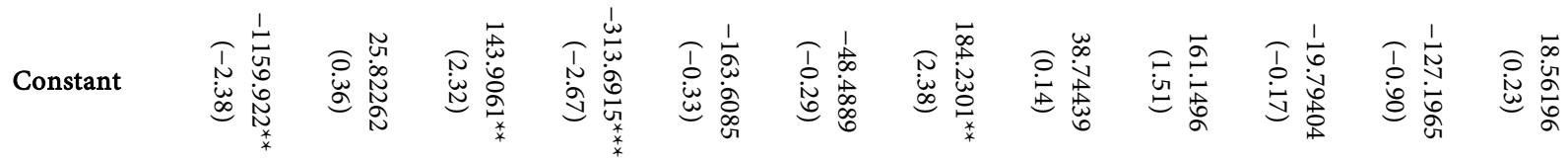

$\begin{array}{ccccccccccccc}\text { Observations } & 20 & 19 & 20 & 19 & 19 & 19 & 18 & 19 & 20 & 18 & 20 & 20 \\ \begin{array}{c}\text { Adjusted } \\ \text { R-squared }\end{array} & 0.2383 & 0.0847 & -0.0452 & 0.4361 & -0.0376 & 0.0094 & -0.0276 & -0.0519 & -0.0470 & 0.0564 & 0.1090 & 0.0546\end{array}$

Notes: $t$-values in parenthesis; ${ }^{* *}$ statistically significant at the $1 \%$ level; ${ }^{* *}$ statistically significant at the $5 \%$ level; ${ }^{*}$ statistically significant at the $10 \%$ level. 
(c)

\begin{tabular}{|c|c|c|c|c|c|c|c|c|c|c|c|c|}
\hline $\begin{array}{l}\text { Variables/ } \\
\text { Regressions }\end{array}$ & (25) & $(26)$ & (27) & $(28)$ & (29) & (30) & $(31)$ & $(32)$ & (33) & $(34)$ & (35) & (36) \\
\hline \multicolumn{13}{|l|}{$\begin{array}{l}\text { Dependent } \\
\text { Variables }\end{array}$} \\
\hline FDI inflows & $\mathrm{X}$ & $\mathrm{X}$ & $\mathrm{X}$ & $\mathrm{X}$ & $\mathrm{X}$ & $\mathrm{X}$ & $\mathrm{X}$ & $\mathrm{X}$ & $\mathrm{X}$ & $\mathrm{X}$ & $\mathrm{X}$ & $\mathrm{X}$ \\
\hline \multicolumn{13}{|l|}{$\begin{array}{c}\text { Independent } \\
\text { Variables }\end{array}$} \\
\hline $\begin{array}{l}\text { Competitiveness } \\
\text { index }\end{array}$ & 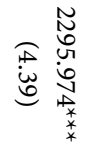 & & & & & & & & & & & \\
\hline Labor cost & & 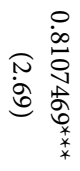 & & & & & & & & & & \\
\hline Political stability & & & 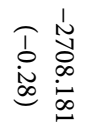 & & & & & & & & & \\
\hline $\begin{array}{l}\text { Corporate income } \\
\text { tax rate }\end{array}$ & & & & 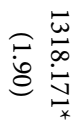 & & & & & & & & \\
\hline $\begin{array}{l}\text { Ease of doing } \\
\text { business }\end{array}$ & & & & & 它 & & & & & & & \\
\hline Corruption & & & & & & 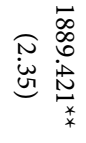 & & & & & & \\
\hline Labor unions & & & & & & & $\begin{array}{l}a \\
\hat{O} \\
\dot{N} \\
\dot{0} \\
0 \\
0 \\
\infty \\
\infty\end{array}$ & & & & & \\
\hline Pensioners & & & & & & & & 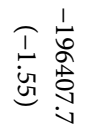 & & & & \\
\hline Unemployment & & & & & & & & & 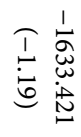 & & & \\
\hline $\begin{array}{c}\text { Pensions as \% of } \\
\text { GDP }\end{array}$ & & & & & & & & & & 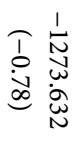 & & \\
\hline Profit tax & & & & & & & & & & & 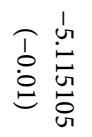 & \\
\hline
\end{tabular}




\section{Continued}

Public debt

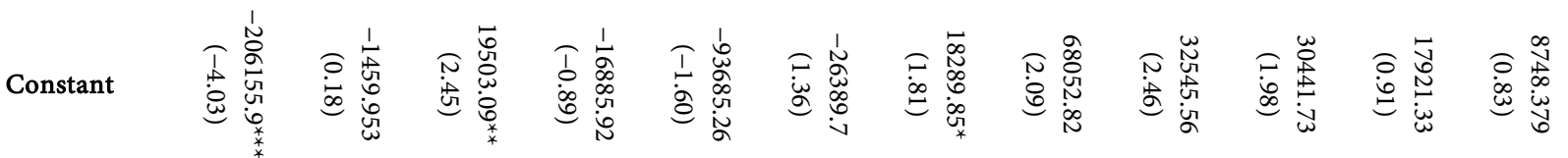

\begin{tabular}{cccccccccccccc}
$\begin{array}{c}\text { Observations } \\
\text { Adjusted }\end{array}$ & 20 & 19 & 20 & 19 & 19 & 19 & 18 & 19 & 20 & 18 & 20 & 20 \\
$\begin{array}{c}\text { R-squared } \\
\text { R-s }\end{array}$ & 0.4897 & 0.2567 & -0.0510 & 0.1270 & 0.1283 & 0.2011 & -0.0621 & 0.0722 & 0.0216 & -0.0232 & -0.0555 & -0.0060 \\
\hline
\end{tabular}

Notes: t-values in parenthesis; ${ }^{* *}$ statistically significant at the $1 \%$ level; ${ }^{* *}$ statistically significant at the $5 \%$ level; ${ }^{*}$ statistically significant at the $10 \%$ level.

(d)

\begin{tabular}{|c|c|c|c|c|c|c|c|c|c|c|c|c|}
\hline $\begin{array}{l}\text { Variables/ } \\
\text { Regressions }\end{array}$ & $(37)$ & $(38)$ & (39) & $(40)$ & $(41)$ & $(42)$ & $(43)$ & $(44)$ & (45) & (46) & $(47)$ & (48) \\
\hline \multicolumn{13}{|l|}{$\begin{array}{c}\text { Dependent } \\
\text { Variables }\end{array}$} \\
\hline GDP growth & $\mathrm{X}$ & $\mathrm{X}$ & $\mathrm{X}$ & $\mathrm{X}$ & $\mathrm{X}$ & $\mathrm{X}$ & $\mathrm{X}$ & $\mathrm{X}$ & $\mathrm{X}$ & $\mathrm{X}$ & $\mathrm{X}$ & $\mathrm{X}$ \\
\hline \multicolumn{13}{|l|}{$\begin{array}{c}\text { Independent } \\
\text { Variables }\end{array}$} \\
\hline $\begin{array}{l}\text { Competitiveness } \\
\text { index }\end{array}$ & 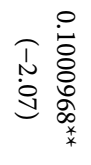 & & & & & & & & & & & \\
\hline Labor cost & & 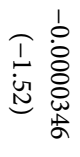 & & & & & & & & & & \\
\hline Political stability & & & 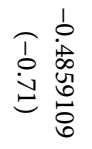 & & & & & & & & & \\
\hline $\begin{array}{l}\text { Corporate income } \\
\text { tax rate }\end{array}$ & & & & 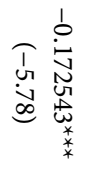 & & & & & & & & \\
\hline $\begin{array}{c}\text { Ease of doing } \\
\text { business }\end{array}$ & & & & & 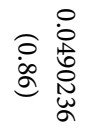 & & & & & & & \\
\hline Corruption & & & & & & 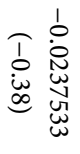 & & & & & & \\
\hline Labor unions & & & & & & & 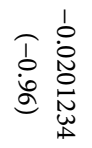 & & & & & \\
\hline
\end{tabular}




\section{Continued}

Pensioners

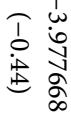

Unemployment

官宫

Pensions as \% of

GDP

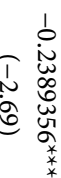

Profit tax

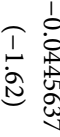

Public debt

Constant 包芯芯过
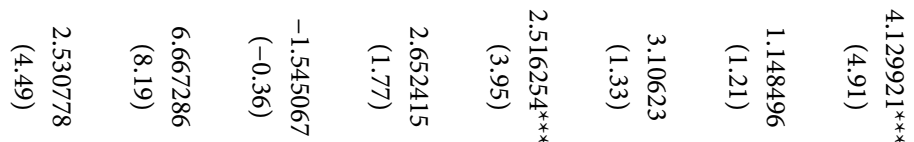

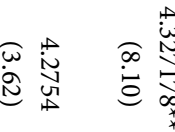

$\begin{array}{ccccccccccccc}\text { Observations } & 20 & 19 & 20 & 19 & 19 & 19 & 18 & 19 & 20 & 18 & 20 & 20 \\ \begin{array}{c}\text { Adjusted } \\ \text { R-squared }\end{array} & 0.1466 & 0.0679 & -0.0270 & 0.6427 & -0.0151 & -0.0498 & -0.0052 & -0.0470 & 0.0204 & 0.2681 & 0.0790 & 0.4907\end{array}$

Notes: $t$-values in parenthesis; ${ }^{* *}$ statistically significant at the $1 \%$ level; ${ }^{*}$ statistically significant at the $5 \%$ level; *statistically significant at the $10 \%$ level.

(e)

\begin{tabular}{|c|c|c|c|c|c|c|c|c|c|c|c|c|}
\hline $\begin{array}{l}\text { Variables/ } \\
\text { Regressions }\end{array}$ & $(49)$ & $(50)$ & $(51)$ & (52) & (53) & (54) & (55) & (56) & (57) & (58) & (59) & $(60)$ \\
\hline $\begin{array}{l}\text { Dependent } \\
\text { Variables }\end{array}$ & & & & & & & & & & & & \\
\hline $\begin{array}{l}\text { GDP per capita } \\
\text { Independent } \\
\text { Variables }\end{array}$ & $\mathrm{x}$ & $\mathrm{x}$ & $\mathrm{x}$ & $\mathrm{X}$ & $\mathrm{X}$ & $\mathrm{X}$ & $\mathrm{X}$ & $\mathrm{X}$ & $\mathrm{X}$ & $\mathrm{X}$ & $\mathrm{x}$ & $\mathrm{X}$ \\
\hline $\begin{array}{l}\text { Competitiveness } \\
\text { index }\end{array}$ & 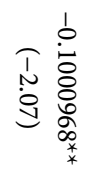 & & & & & & & & & & & \\
\hline Labor cost & & 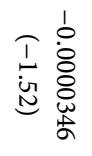 & & & & & & & & & & \\
\hline Political stability & & & 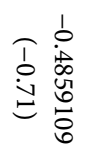 & & & & & & & & & \\
\hline
\end{tabular}




\section{Continued}

Corporate income tax rate

Ease of doing

business

Corruption

Labor unions

Pensioners

Unemployment

Pensions as \% of GDP

Profit tax

Public debt

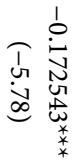

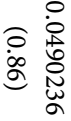

I

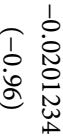

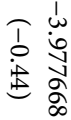

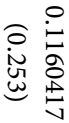

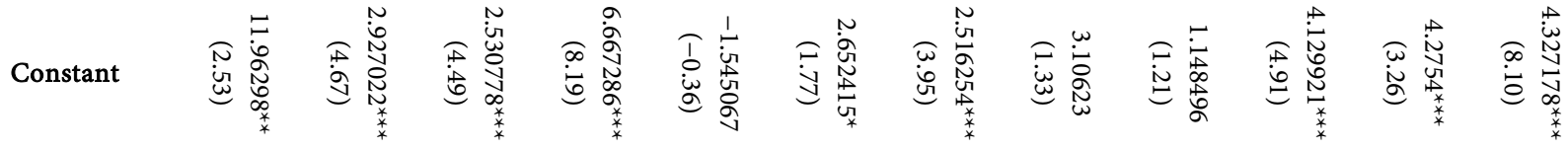

$\begin{array}{ccccccccccccc}\text { Observations } & 20 & 19 & 20 & 19 & 19 & 19 & 18 & 19 & 20 & 18 & 20 & 20 \\ \begin{array}{c}\text { Adjusted } \\ \text { R-squared }\end{array} & 0.1466 & 0.0679 & -0.0270 & 0.6427 & -0.0151 & -0.0498 & -0.0052 & -0.0470 & 0.0204 & 0.2681 & 0.0790 & 0.4907\end{array}$

Notes: $t$-values in parenthesis; ${ }^{* *}$ statistically significant at the $1 \%$ level; ${ }^{* *}$ statistically significant at the $5 \%$ level; ${ }^{*}$ statistically significant at the $10 \%$ level. 
(f)

\begin{tabular}{|c|c|c|c|c|c|c|c|c|c|c|c|c|}
\hline $\begin{array}{l}\text { Variables/ } \\
\text { Regressions }\end{array}$ & $(61)$ & $(62)$ & (63) & $(64)$ & $(65)$ & $(66)$ & $(67)$ & $(68)$ & (69) & (70) & (71) & $(72)$ \\
\hline \multicolumn{13}{|l|}{$\begin{array}{l}\text { Dependent } \\
\text { Variables }\end{array}$} \\
\hline GDP & $\mathrm{X}$ & $\mathrm{X}$ & $\mathrm{X}$ & $\mathrm{X}$ & $\mathrm{X}$ & $\mathrm{X}$ & $\mathrm{X}$ & $\mathrm{X}$ & $\mathrm{X}$ & $\mathrm{X}$ & $\mathrm{X}$ & $\mathrm{X}$ \\
\hline \multicolumn{13}{|l|}{$\begin{array}{l}\text { Independent } \\
\text { Variables }\end{array}$} \\
\hline $\begin{array}{l}\text { Competitiveness } \\
\text { index }\end{array}$ & 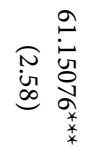 & & & & & & & & & & & \\
\hline Labor cost & & 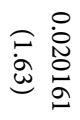 & & & & & & & & & & \\
\hline Political stability & & & 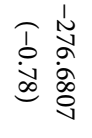 & & & & & & & & & \\
\hline $\begin{array}{l}\text { Corporate income } \\
\text { tax rate }\end{array}$ & & & & 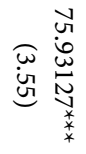 & & & & & & & & \\
\hline $\begin{array}{l}\text { Ease of doing } \\
\text { business }\end{array}$ & & & & & 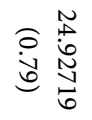 & & & & & & & \\
\hline Corruption & & & & & & 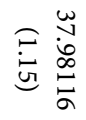 & & & & & & \\
\hline Labor unions & & & & & & & 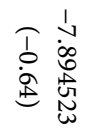 & & & & & \\
\hline Pensioners & & & & & & & & 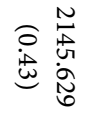 & & & & \\
\hline Unemployment & & & & & & & & & 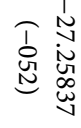 & & & \\
\hline $\begin{array}{c}\text { Pensions as \% of } \\
\text { GDP }\end{array}$ & & & & & & & & & & 它 & & \\
\hline Profit tax & & & & & & & & & & & 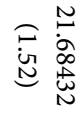 & \\
\hline Public debt & & & & & & & & & & & & 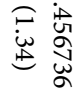 \\
\hline
\end{tabular}




\section{Continued}

\begin{tabular}{|c|c|c|c|c|c|c|c|c|c|c|c|c|}
\hline Constant & 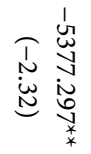 & 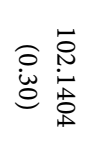 & 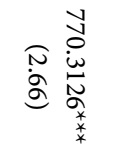 & 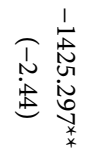 & 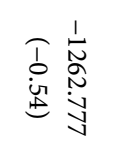 & 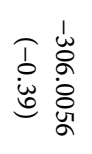 & 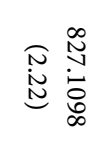 & 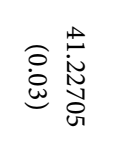 & 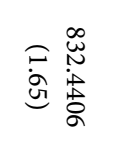 & 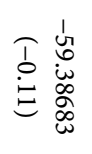 & 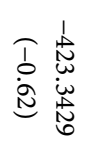 & 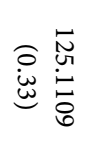 \\
\hline Observations & 20 & 19 & 20 & 19 & 19 & 19 & 18 & 19 & 20 & 18 & 20 & 20 \\
\hline $\begin{array}{l}\text { Adjusted } \\
\text { R-squared }\end{array}$ & 0.2287 & 0.0836 & -0.0207 & 0.3914 & -0.0214 & 0.0179 & -0.0358 & -0.0474 & -0.0398 & 0.0378 & 0.0645 & 0.0408 \\
\hline
\end{tabular}

Notes: t-values in parenthesis; ${ }^{* *}$ statistically significant at the $1 \%$ level; ${ }^{* *}$ statistically significant at the $5 \%$ level; ${ }^{*}$ statistically significant at the $10 \%$ level.

(g)

\begin{tabular}{|c|c|c|c|c|c|c|c|c|c|c|c|c|}
\hline $\begin{array}{l}\text { Variables/ } \\
\text { Regressions }\end{array}$ & (73) & (74) & (75) & (76) & $(77)$ & (78) & (79) & (80) & (81) & (82) & (83) & (84) \\
\hline \multicolumn{13}{|l|}{$\begin{array}{l}\text { Dependent } \\
\text { Variables }\end{array}$} \\
\hline CPI & $\mathrm{X}$ & $\mathrm{X}$ & $\mathrm{x}$ & $\mathrm{x}$ & $\mathrm{x}$ & $\mathrm{X}$ & $\mathrm{X}$ & $\mathrm{X}$ & $\mathrm{x}$ & $\mathrm{x}$ & $\mathrm{x}$ & $\mathrm{x}$ \\
\hline \multicolumn{13}{|l|}{$\begin{array}{l}\text { Independent } \\
\text { Variables }\end{array}$} \\
\hline $\begin{array}{l}\text { Competitiveness } \\
\text { index }\end{array}$ & 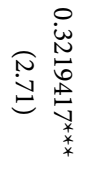 & & & & & & & & & & & \\
\hline Labor cost & & 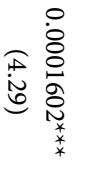 & & & & & & & & & & \\
\hline Political stability & & & 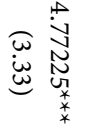 & & & & & & & & & \\
\hline $\begin{array}{l}\text { Corporate income } \\
\text { tax rate }\end{array}$ & & & & 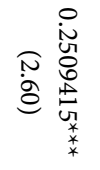 & & & & & & & & \\
\hline $\begin{array}{l}\text { Ease of doing } \\
\text { business }\end{array}$ & & & & & 官 & & & & & & & \\
\hline Corruption & & & & & & 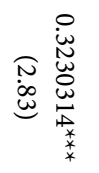 & & & & & & \\
\hline Labor unions & & & & & & & 局总 & & & & & \\
\hline Pensioners & & & & & & & & 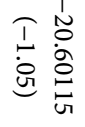 & & & & \\
\hline
\end{tabular}




\section{Continued}

Unemployment

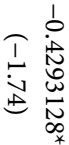

Pensions as \% of

GDP

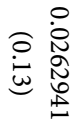

Profit tax

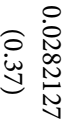

Public debt

苨兑

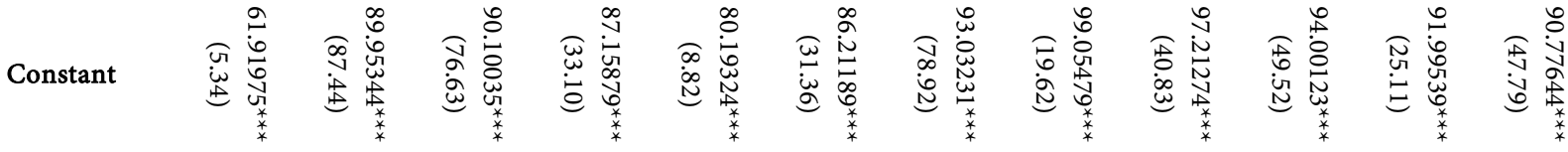

$\begin{array}{ccccccccccccc}\begin{array}{c}\text { Observations } \\ \text { Adjusted }\end{array} & 20 & 19 & 20 & 19 & 19 & 19 & 18 & 19 & 20 & 18 & 20 & 20 \\ \begin{array}{c}\text { R-squared } \\ \text { R }\end{array} & 0.2502 & 0.4914 & 0.3465 & 0.2418 & 0.0652 & 0.2803 & 0.0218 & 0.0055 & 0.0964 & -0.0614 & -0.0477 & 0.0579\end{array}$

Notes: $t$-values in parenthesis; ${ }^{* *}$ statistically significant at the $1 \%$ level; ${ }^{* *}$ statistically significant at the $5 \%$ level; ${ }^{*}$ statistically significant at the $10 \%$ level.

(h)

\begin{tabular}{|c|c|c|c|c|c|c|c|c|c|c|c|c|}
\hline $\begin{array}{l}\text { Variables/ } \\
\text { Regressions }\end{array}$ & $(85)$ & $(86)$ & $(87)$ & $(88)$ & $(89)$ & (90) & (91) & (92) & (93) & (94) & (95) & (96) \\
\hline $\begin{array}{c}\text { Dependent } \\
\text { Variables }\end{array}$ & & & & & & & & & & & & \\
\hline Consumption & $\mathrm{X}$ & $\mathrm{X}$ & $\mathrm{X}$ & $\mathrm{X}$ & $\mathrm{X}$ & $\mathrm{X}$ & $\mathrm{X}$ & $\mathrm{X}$ & $\mathrm{X}$ & $\mathrm{x}$ & $\mathrm{X}$ & $\mathrm{X}$ \\
\hline $\begin{array}{c}\text { Independent } \\
\text { Variables }\end{array}$ & & & & & & & & & & & & \\
\hline $\begin{array}{l}\text { Competitiveness } \\
\text { index }\end{array}$ & 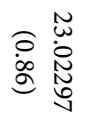 & & & & & & & & & & & \\
\hline Labor cost & & 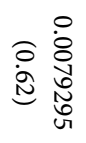 & & & & & & & & & & \\
\hline Political stability & & & $\underset{\text { Oे }}{\stackrel{\omega}{\omega} \underset{\omega}{\omega}}$ & & & & & & & & & \\
\hline $\begin{array}{l}\text { Corporate income } \\
\text { tax rate }\end{array}$ & & & & 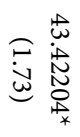 & & & & & & & & \\
\hline $\begin{array}{c}\text { Ease of doing } \\
\text { business }\end{array}$ & & & & & 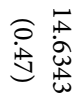 & & & & & & & \\
\hline
\end{tabular}




\section{Continued}

\section{Corruption}

Labor unions

Pensioners

Unemployment

Pensions as \% of

GDP

Profit tax

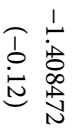

○े

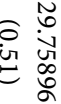

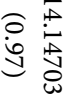

Public debt

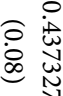

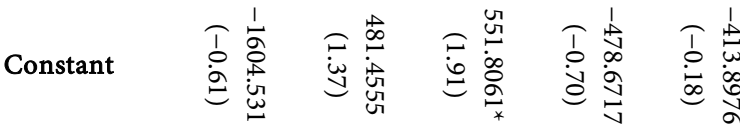

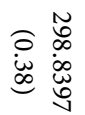

Ț

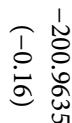

숭

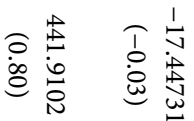

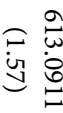

$\begin{array}{ccccccccccccc}\text { Observations } & 20 & 19 & 20 & 19 & 19 & 19 & 18 & 19 & 20 & 18 & 20 & 20 \\ \begin{array}{c}\text { Adjusted } \\ \text { R-squared }\end{array} & -0.0140 & -0.0352 & -0.0475 & 0.0992 & -0.0450 & -0.0444 & -0.0616 & -0.0275 & -0.0075 & -0.0456 & -0.0029 & -0.0552 \\ \end{array}$

Notes: $\mathrm{t}$-values in parenthesis; ${ }^{* * *}$ statistically significant at the $1 \%$ level; ${ }^{* *}$ statistically significant at the $5 \%$ level; ${ }^{*}$ statistically significant at the $10 \%$ level. Source: Results of regressions run by the authors using data from the World Bank and the OECD (averages of years 2000-2015).

(i)

\begin{tabular}{|c|c|c|c|c|c|c|c|c|c|c|c|c|}
\hline $\begin{array}{l}\text { Variables/ } \\
\text { Regressions }\end{array}$ & (97) & (98) & (99) & (100) & (101) & (102) & (103) & (104) & (105) & (106) & (107) & (108) \\
\hline $\begin{array}{c}\text { Dependent } \\
\text { Variables }\end{array}$ & & & & & & & & & & & & \\
\hline Imports & $\mathrm{X}$ & $\mathrm{X}$ & $\mathrm{X}$ & $\mathrm{X}$ & $\mathrm{X}$ & $\mathrm{X}$ & $\mathrm{X}$ & $\mathrm{X}$ & $\mathrm{X}$ & $\mathrm{X}$ & $\mathrm{X}$ & $\mathrm{X}$ \\
\hline $\begin{array}{c}\text { Independent } \\
\text { Variables }\end{array}$ & & & & & & & & & & & & \\
\hline $\begin{array}{l}\text { Competitiveness } \\
\text { index }\end{array}$ & 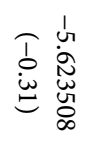 & & & & & & & & & & & \\
\hline Labor cost & & 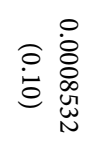 & & & & & & & & & & \\
\hline
\end{tabular}




\section{Continued}

Political stability

Corporate income

tax rate

\section{Ease of doing \\ business}

Corruption

Labor unions

Pensioners

Unemployment

Pensions as \% of GDP

\section{Profit tax}

Public debt

\section{. \\ 论}

ô

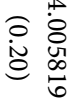

○े

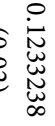

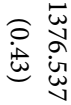

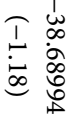

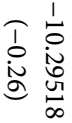

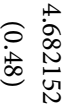

I $\frac{1}{\sim}$

\begin{tabular}{ccccccccccccc} 
Observations & 20 & 19 & 20 & 19 & 19 & 19 & 18 & 19 & 20 & 18 & 20 & 20 \\
$\begin{array}{c}\text { Adjusted } \\
\text { R-squared }\end{array}$ & -0.0498 & -0.0582 & -0.0190 & -0.0372 & -0.0564 & -0.0577 & -0.0625 & -0.0473 & 0.0205 & -0.0579 & -0.0422 & -0.0353 \\
\hline
\end{tabular}

Notes: $t$-values in parenthesis; ${ }^{* *}$ statistically significant at the $1 \%$ level; ${ }^{*}$ statistically significant at the $5 \%$ level; ${ }^{*}$ statistically significant at the $10 \%$ level. Source: Results of regressions run by the authors using data from the World Bank and the OECD (averages of years 2000-2015).

(j)

\begin{tabular}{|c|c|c|c|c|c|c|c|c|c|c|c|c|}
\hline $\begin{array}{l}\text { Variables/ } \\
\text { Regressions }\end{array}$ & (109) & (110) & (111) & (112) & (113) & (114) & (115) & (116) & (117) & (118) & (119) & (120) \\
\hline $\begin{array}{c}\text { Dependent } \\
\text { Variables }\end{array}$ & & & & & & & & & & & & \\
\hline Exports & $\mathrm{X}$ & $\mathrm{X}$ & $\mathrm{X}$ & $\mathrm{X}$ & $\mathrm{X}$ & $\mathrm{X}$ & $\mathrm{X}$ & $\mathrm{X}$ & $\mathrm{X}$ & $\mathrm{X}$ & $\mathrm{X}$ & $\mathrm{X}$ \\
\hline
\end{tabular}




\section{Continued \\ Independent \\ Variables

\begin{tabular}{|c|c|}
\hline $\begin{array}{l}\text { Competitiveness } \\
\text { index }\end{array}$ & 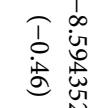 \\
\hline Labor cost & \\
\hline
\end{tabular}

Political stability

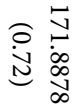

Corporate income tax rate

○े

\section{Ease of doing business}

Corruption

Labor unions

Pensioners

Unemployment

Pensions as \% of GDP

Profit tax

Public debt

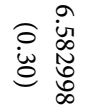

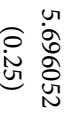

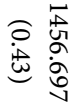

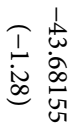

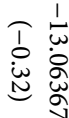

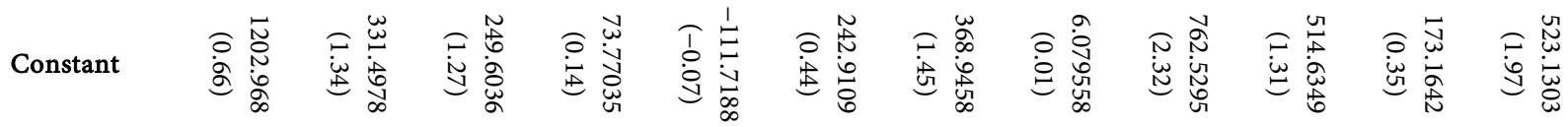

$\begin{array}{lllllllllllll}\text { Observations } & 20 & 19 & 20 & 19 & 19 & 19 & 18 & 19 & 20 & 18 & 20 & 20\end{array}$




\section{Continued}

$\begin{array}{ccccccccccccc}\text { Adjusted } & -0.0433 & -0.0561 & -0.0263 & -0.0364 & -0.0531 & -0.0550 & -0.0614 & -0.0472 & 0.0326 & -0.0559 & -0.0461 & -0.0307 \\ \text { R-squared } & & & & & & \end{array}$

Notes: $t$-values in parenthesis; ${ }^{* * *}$ statistically significant at the $1 \%$ level; ${ }^{* *}$ statistically significant at the $5 \%$ level; ${ }^{*}$ statistically significant at the $10 \%$ level. Source: Results of regressions run by the authors using data from the World Bank and the OECD (averages of years 2000-2015).

(k)

\begin{tabular}{|c|c|c|c|c|c|c|c|c|c|c|c|}
\hline $\begin{array}{l}\text { Variables/ } \\
\text { Regressions }\end{array}$ & $(121)$ & $(122)$ & (123) & $(124)$ & $(125)$ & (126) & (127) & $(128)$ & (129) & (130) & (131) \\
\hline \multicolumn{12}{|l|}{$\begin{array}{c}\text { Dependent } \\
\text { Variables }\end{array}$} \\
\hline Unemployment & $\mathrm{X}$ & $\mathrm{X}$ & $\mathrm{X}$ & $\mathrm{X}$ & $\mathrm{X}$ & $\mathrm{X}$ & $\mathrm{X}$ & $\mathrm{X}$ & $\mathrm{X}$ & $\mathrm{X}$ & $\mathrm{X}$ \\
\hline \multicolumn{11}{|l|}{ Independent } & \\
\hline $\begin{array}{l}\text { Competitiveness } \\
\text { index }\end{array}$ & 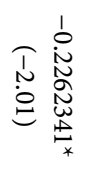 & & & & & & & & & & \\
\hline Labor cost & & 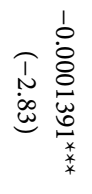 & & & & & & & & & \\
\hline Political stability & & & 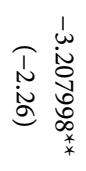 & & & & & & & & \\
\hline $\begin{array}{l}\text { Corporate income } \\
\text { tax rate }\end{array}$ & & & & 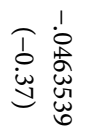 & & & & & & & \\
\hline $\begin{array}{c}\text { Ease of doing } \\
\text { business }\end{array}$ & & & & & 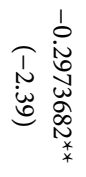 & & & & & & \\
\hline Corruption & & & & & & 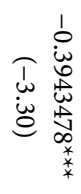 & & & & & \\
\hline Labor unions & & & & & & & 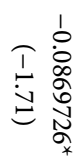 & & & & \\
\hline Pensioners & & & & & & & & 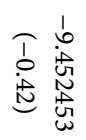 & & & \\
\hline $\begin{array}{l}\text { Pensions as } \% \text { of } \\
\text { GDP }\end{array}$ & & & & & & & & & 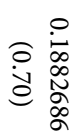 & & \\
\hline
\end{tabular}




\section{Continued}

Profit tax

Public debt

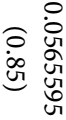

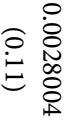

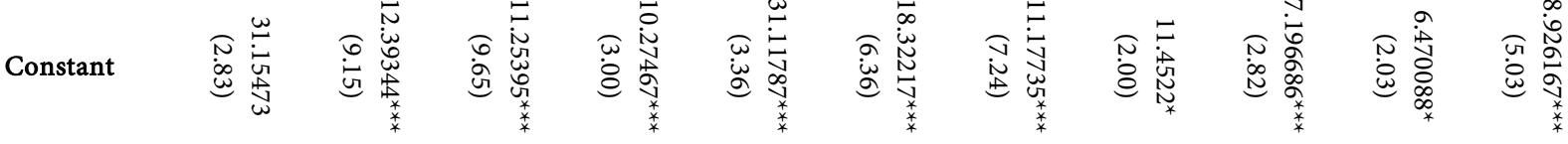

$\begin{array}{cccccccccccc}\text { Observations } & 20 & 19 & 20 & 19 & 19 & 19 & 18 & 19 & 18 & 20 & 20 \\ \begin{array}{c}\text { Adjusted } \\ \text { R-squared }\end{array} & 0.1378 & 0.2796 & 0.1771 & -0.0504 & 0.2073 & 0.3539 & 0.1010 & -0.0478 & -0.0312 & -0.0150 & -0.0549\end{array}$

Notes: t-values in parenthesis; ${ }^{* *}$ statistically significant at the $1 \%$ level; ${ }^{* *}$ statistically significant at the $5 \%$ level; ${ }^{*}$ statistically significant at the $10 \%$ level. Source: Results of regressions run by the authors using data from the World Bank and the OECD (averages of years 2000-2015).

(l)

\begin{tabular}{|c|c|c|c|c|c|c|c|c|c|c|c|}
\hline $\begin{array}{l}\text { Variables/ } \\
\text { Regressions }\end{array}$ & $(132)$ & (133) & $(134)$ & (135) & $(136)$ & (137) & (138) & (139) & (140) & (141) & $(142)$ \\
\hline $\begin{array}{l}\text { Dependent } \\
\text { Variables }\end{array}$ & & & & & & & & & & & \\
\hline Public Debt & $\mathrm{X}$ & $\mathrm{X}$ & $\mathrm{X}$ & $\mathrm{X}$ & $\mathrm{X}$ & $\mathrm{X}$ & $\mathrm{X}$ & $\mathrm{X}$ & $\mathrm{X}$ & $\mathrm{X}$ & $\mathrm{X}$ \\
\hline $\begin{array}{l}\text { Independent } \\
\text { Variables }\end{array}$ & & & & & & & & & & & \\
\hline $\begin{array}{l}\text { Competitiveness } \\
\text { index }\end{array}$ & 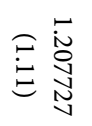 & & & & & & & & & & \\
\hline Labor cost & & 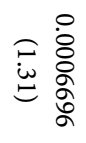 & & & & & & & & & \\
\hline Political stability & & & 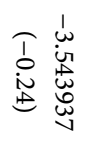 & & & & & & & & \\
\hline $\begin{array}{l}\text { Corporate income } \\
\text { tax rate }\end{array}$ & & & & 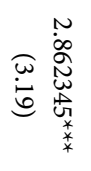 & & & & & & & \\
\hline $\begin{array}{c}\text { Ease of doing } \\
\text { business }\end{array}$ & & & & & 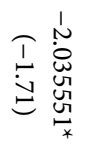 & & & & & & \\
\hline Corruption & & & & & & 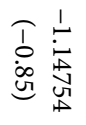 & & & & & \\
\hline
\end{tabular}




\section{Continued}

Labor unions

Pensioners

Unemployment

Pensions as \% of

GDP

Profit tax

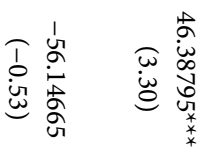

Observations

Adjusted

R-squared
20

0.0120
19

0.0387

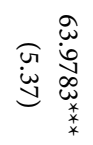

20

$-0.0521$

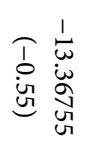

19

0.3382

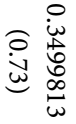

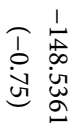

○通

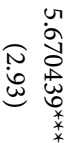

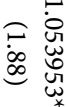

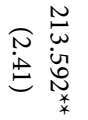

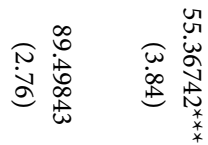

它

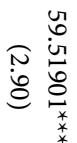

它

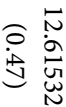

19

19

18

19

20

18

20

0.0962

$-0.015$

$-0.027$

$-0.024$

$-0.054$

0.3092

0.1172

Notes: $t$-values in parenthesis; ${ }^{* *}$ statistically significant at the $1 \%$ level; ${ }^{*}$ statistically significant at the $5 \%$ level; ${ }^{*}$ statistically significant at the $10 \%$ level. Source: Results of regressions run by the authors using data from the World Bank and the OECD (averages of years 2000-2015).

\subsection{Results and Implications}

From the regressions of investments/GDP with each of the independent variables we realize that it is negatively correlated with the competitiveness index and the public debt at all levels, as well as with the labor cost and the corporate tax rate at the $5 \%$ level. The remaining variables show no statistical significance. This means that the higher the public debt, the corporate income tax rate and the labor cost, the lower are the investments as a portion of GDP. This could be somehow anticipated as investments are more likely discouraged when the public debt, the corporate income tax rate and the labor cost are too high. On the other hand, the relation of investments/GDP with the competitiveness index is probably explained by the fact that countries which are perceived as competitive have already attracted investments and their portion in the GDP is not as high compared with countries which are not considered as competitive. It is possible that the latter have lower GDP amounts-in line with their lower competitiveness (as evidenced with the GDP regressions below) - versus their investment amounts and this justifies the negative correlation. 
Gross fixed capital formation is positively correlated with the competitiveness index at the 5\% level, with the corporate income tax rate at all levels and with the profit tax rate at the $10 \%$ level. The rest of the variables exhibit no statistical significance. These findings most show that the highest the competitiveness there is a tendency to invest rather than consume. The same is reflected by the level of tax rates that affect the enterprises.

FDI inflows are positively correlated with the competitiveness index at all levels, with the labor cost and corruption at the $5 \%$ level, the corporate income tax rate and the ease of doing business at the $10 \%$ level. There is no statistically significant correlation with the other independent variables. The outcomes of the FDI regressions indicate that the higher the perceived level of competitiveness, the ease of doing business and the lower the corruption the more the FDI inflows attracted are. The relation of the FDI inflows with the labor cost and the corporate income tax rate could be explained by the fact that the countries that exhibit high levels of FDI inflows have already established the conditions that justify higher wages and tax rate.

The GDP growth is negatively correlated with the competitiveness index at the $5 \%$ level and with the corporate income tax rate, the pensions as a percent of GDP and the public debt at all levels. The other variables show no explanatory significance. This means that to achieve GDP growth the perceived competitiveness needs to be high, not only as reflected by the relevant index, but also as measured with the tax rate, the pensions and the public debt. This is probably expected as a high level of pensions as a percent of GDP or public debt can be showstoppers.

The GDP per capita (and productivity) is negatively correlated with the competitiveness index at the $5 \%$ level and with the corporate tax rate, the pensions as a percent of GDP and the public debt at all levels. The remaining variables exhibit no statistical significance. This indicates that countries that have achieved high levels of GDP per capita have lower corporate income tax rates, lower pensions as a percent of GDP and lower public debt. The correlation with the competitiveness index can be probably explained by the fact that countries that have high perceived competitiveness already have high levels of GDP per capita, however their order is not the same.

The GDP is positively correlated with the competitiveness index and the corporate income tax rate at all levels, whereas no other variable shows any statistical significance. Apparently countries that are perceived as highly competitive already have high GDP levels and can afford to apply relatively higher corporate income tax rates.

The CPI is positively correlated with the competitiveness index, the labor cost, the political stability, the corporate income tax rate and the corruption at all levels and negatively correlated with the unemployment level. The rest of the variables do not exhibit any explanatory power. If CPI is seen as an indicator whose increase signals the exit from a recessionary period, then countries with high 
perceived competitiveness, political stability, low corruption and low unemployment are benefited the most. They can afford higher corporate income tax rate and labor cost.

Unemployment is negatively correlated with the labor cost and corruption at all levels, with political stability and ease of doing business at the 5\% level and with the competitiveness index and labor unions at the $10 \%$ level. The remaining variables show no statistical significance. Consequently, the lower the perceived level of corruption, the higher the perceived ease of doing business, the political stability and the competitiveness, the lower the unemployment is. The relationship between unemployment and labor cost as well as labor unions can be probably explained by the fact that countries that exhibit such characteristics can afford higher remunerations and more labor unions. It could also be that the more the labor unions, the lower the level of unemployment achieved is.

The public debt is positively correlated with the pensions as a percent of GDP and the corporate tax rate at all levels, with the profit tax rate at the $10 \%$ level and negatively correlated with the ease of doing business at the $10 \%$ level. The rest of the variables do not exhibit any statistical significance. As a result, the higher the pensions as a percent of GDP and the lower the ease of doing business the higher the debt. The positive correlation of the public debt with the corporate income tax rate and the profit tax rate could be probably explained by the fact that countries with high public debt finally apply high tax rates.

Consumption is positively correlated with the corporate income tax rate at the $10 \%$ level, whereas the other variables have no statistically significant correlation. Such a finding means that countries with higher consumption can afford to charge higher corporate income tax rate.

Finally, imports and exports show no statistically significant correlation with any of the variables.

We summarize the aforementioned results in terms of the correlations between the dependent and independent variables, without mentioning the significance level, in the following Table 3. Such a tabular representation helps in understanding the explanatory value of the independent variables.

We realize that the perceived competitiveness as captured by the competitiveness index is indeed important for most of the dependent variables and thus key for the effectiveness of an adjustment program and the same holds true for the corporate income tax rate. The labor cost, public debt and the corruption come next. The political stability and the profit tax rate follow. The ease of doing business, the (number of) labor unions, the pensioners (percent) and the pensions (as a \% of GDP) seem to influence the smallest number of dependent variables. The implications of each of the correlations have already been explained in the previous paragraphs of this section that analyze each of the regressions.

\subsubsection{Heteroskedasticity Test}

We tested the above regressions for heteroskedasticity. To detect this we used White's test to find that that regressions $16,29,64,74,76$ (Table 2) seem to 
Table 3. Correlations

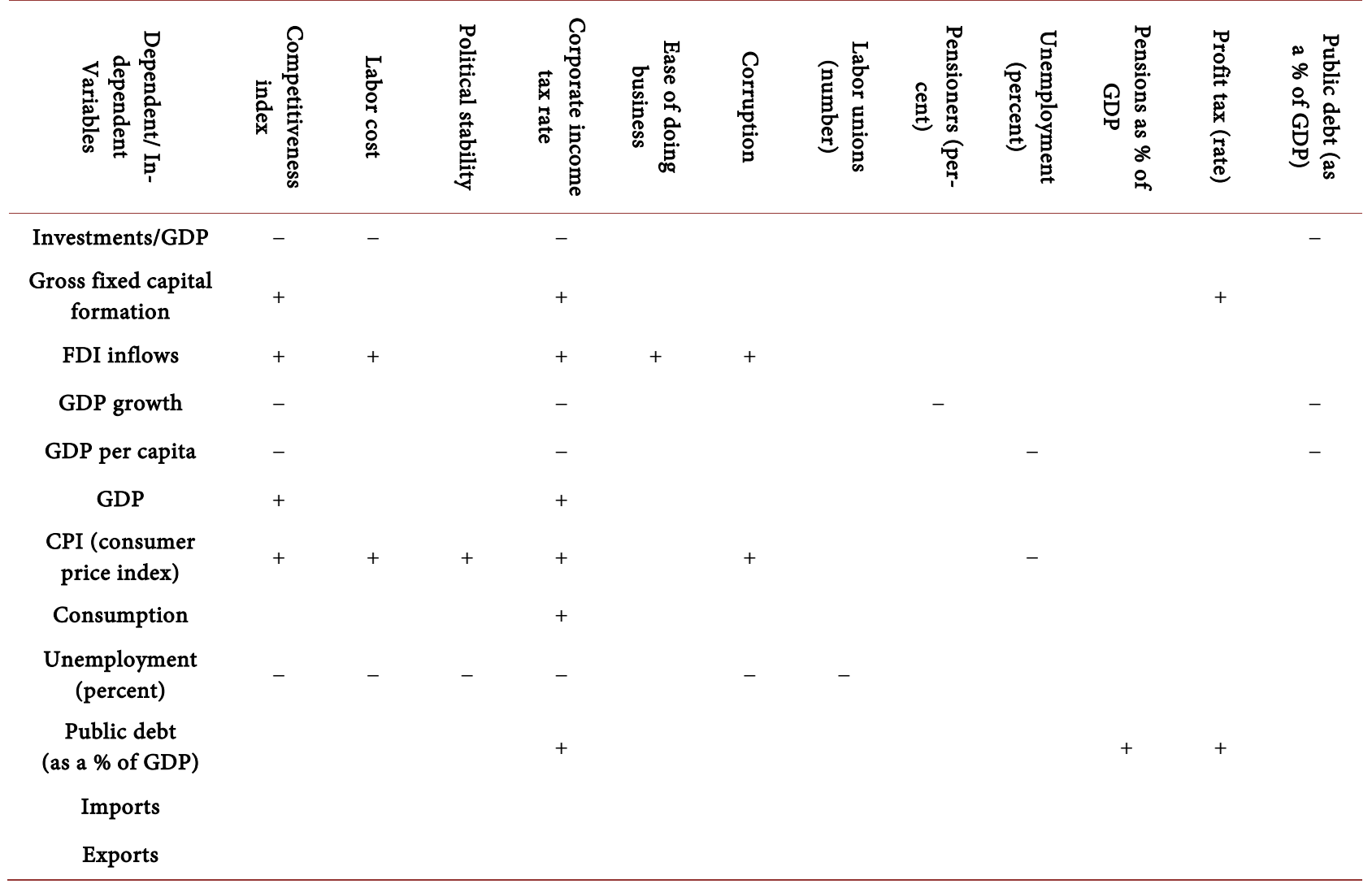

Source: Results of regressions run by the authors using data from the World Bank and the OECD (averages of years 2000-2015).

exhibit heteroskedasticity (violating the $10 \%$ threshold, although not the $1 \%$ level). We corrected it by using the robust standard errors approach (16, 64, 74, 76 corrected, 29 not corrected).

\subsubsection{Regressions Eurozone}

We performed similar regressions only for the 14 of the above countries that use euro as their currency, i.e. Austria, Belgium, Estonia, France, Germany, Greece, Ireland, Italy, Latvia, Netherlands, Portugal, Slovak, Slovenia and Spain. The results are comparable with small differences in some of the levels of statistical significance. We note that the ease of doing business is positively correlated at the 5\% level with the GDP growth and GDP per capita whereas it was not statistically significant for the 20 countries. This remark highlights further the importance of the perception reflected by this indicator. In addition imports and exports are positively correlated with the competitiveness index and the labor cost at the $10 \%$ level and with the corporate income tax rate at the $1 \%$ and $5 \%$ level respectively. These findings are probably explained by the fact that the majority of these countries have the levels of their imports and exports at a level aligned with their corporate income tax rate, labor cost and competitiveness. We skip the corresponding regressions tables as it would tremendously increase the size of the paper. We only include a correlations table, similar to Table 3 but limited 
to the countries of the Eurozone (Table 4).

The aforementioned findings of the regression analysis are globally in line with the analysis of the structural weaknesses of the Greek economy which led to the limited effectiveness of the adjustment programs as presented in section 3 . The relationships identified among the measures of the structural weakness or strength of a country and the determinants of the effectiveness of an adjustment program indicate that a country like Greece that wishes to meet the targets set needs to foster its competitiveness as measured by the relevant index as well as the corporate income tax rate, the profit tax rate, the ease of doing business as well as the perceived level of corruption and political stability. It has to reduce its public debt as well as pensions as a percent of GDP. As mentioned in Section 3, especially for the case of Greece, the pensions paid are a significant contributor to the formulation of public debt. Labor cost seems to be working both ways; however in order to attract investments and achieve an internal devaluation the labor cost has to be reduced.

\section{Conclusions}

The reason for this analysis was the prolonged recession in Greece, which has been longer and deeper than anticipated. There is no doubt that the fiscal, and income, austerity policy, together with political uncertainty and delays in privatisation were

Table 4. Correlations Eurozone.

\begin{tabular}{|c|c|c|c|c|c|c|c|c|c|c|c|c|}
\hline 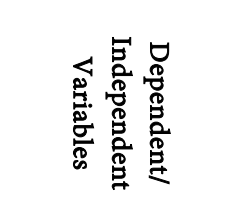 & 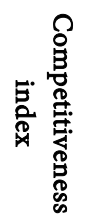 & 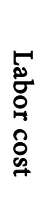 & 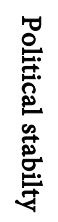 & 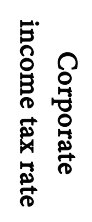 & 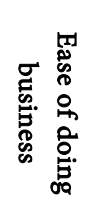 & 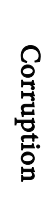 & 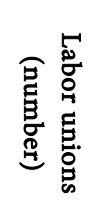 & 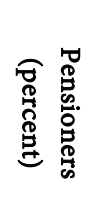 & 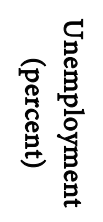 & 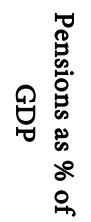 & 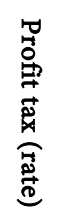 & 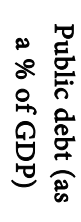 \\
\hline Investments/GDP & - & - & & - & & & & & & - & & - \\
\hline $\begin{array}{l}\text { Gross fixed capital } \\
\text { formation }\end{array}$ & + & & & + & & & & & & & + & \\
\hline FDI inflows & + & + & & + & & + & & & & & & \\
\hline GDP growth & - & & & - & + & & & - & & & & - \\
\hline GDP per capita & - & & & - & + & & & & - & & - & - \\
\hline GDP & + & & & + & & & & & & & - & \\
\hline $\begin{array}{l}\text { CPI (consumer } \\
\text { price index) }\end{array}$ & + & + & & + & & + & & & - & & & \\
\hline Consumption & & & & + & & & & & & + & + & \\
\hline $\begin{array}{l}\text { Unemployment } \\
\text { (percent) }\end{array}$ & - & - & - & & - & - & - & & & & & \\
\hline $\begin{array}{c}\text { Public debt } \\
\text { (as a \% of GDP) }\end{array}$ & & & & + & & & & & & + & + & \\
\hline Imports & + & + & & + & & & & & & & & \\
\hline Exports & + & + & & + & & & & & & & & \\
\hline
\end{tabular}

Source: Results of regressions run by the authors using data from the World Bank and the OECD (averages of years 2000-2015). 
major causes of the recession. The adjustment policy implemented to date was primarily focused on fiscal consolidation and internal devaluation and, in the long term, on a series of institutional and organisations reforms of the state and the economy. From the outset, the economic policy mix that is implemented through the memorandums focused on treating the symptoms of the crisis, instead of drastically dealing with its root causes. These causes include the structural weaknesses of the Greek economies, such as its limited productive and innovative capacity; the predominance of traditional, less knowledge- and technology-intensive sectors; and the introversion of the productive system, and the low percentage of exports, as well as the limited participation of Greek enterprises in international production and distribution chains. GDP formation was, for many decades, mainly based on domestic consumption, and less on investment. Moreover, a series of flaws in the organisation and operation of the political and economic system, such as clientelism, corruption, bureaucracy, over-regulation, market rigidity, reduced domestic competition, legislative complexity and legal uncertainty, the instability and complexity of the tax system, and the obstacles to doing business, were major impediments to investment, entrepreneurship, and competitiveness long before the 2009 crisis. Finally, the deterioration of public finances, and over-indebtedness were primarily due to two chronic ills of the public economy, namely the excessive spending on, and subsidisation of, the pension system, and high tax evasion.

The examination of the above structural and systemic weaknesses, which constituted the deeper causes of the crisis, reveals that, despite any marginal improvements, their vast majority continues to exist and to prevent the country from exiting the recession and entering a new era of modern institutions and a competitive economy. Therefore, the adjustment policy will not help the country enter a path of sustainable growth, unless it solves the chronic weaknesses and ills of the Greek economy and public administration. Persistence in macroeconomic adjustment policies-which are indeed necessary-is not enough for permanently solving the Greek problem. The country needs a strong structural policy that will help it acquire a new production model [47], based on extroversion, innovation and sound entrepreneurship, and a domestic economic system with functioning markets, stable and transparent institutions, and an effective public administration. This is evidenced by the regression analysis performed, comparing the relevant figures of our countries of interest.

\section{Conflicts of Interest}

The authors declare no conflicts of interest regarding the publication of this paper.

\section{References}

[1] IMF (2017) Greece Ex-Post Evaluation Access under the 2012 Extended Arrangement-Press Release; Staff Report; and Statement by the Executive Director for Greece. IMF Country Report No. 17/44, Washington DC. 
[2] IMF (2017) Greece 2016 Article IV Consultation-Press Release; Staff Report; and Statement by the Executive Director for Greece. IMF Country Report No. 17/40, Washington DC.

[3] Pelagidis, T. and Mitsopoulos, M. (2016) Who's to Blame for Greece? Austerity in Charge of Saving a Broken Economy. Palgrave Macmillan, New York.

[4] Ioannides, Y.M. and Pissarides, A.C. (2015) Is the Greek Debt Crisis One of Supply or Demand?

https://www.brookings.edu/bpea-articles/is-the-greek-debt-crisis-one-of-supply-ordemand/

[5] Thomsen, P. (2016) Greece: Toward a Workable Program. IMF Direct. https://blog-imfdirect.imf.org/2016/02/11/greece-toward-a-workable-program/

[6] Sinn, H.-W. (2015) The Greek Tragedy. https://www.cesifo-group.de/ifoHome/publications/journals/CESifo-Forum/Archiv /CESifo-Forum-2015.html

[7] Papadimitriou, D.B., Nikiforos, M. and Zezza, G. (2013) The Greek Economic Crisis and the Experience of Austerity: A Strategic Analysis.

http://www.levyinstitute.org/pubs/sa_gr_7_13.pdf

[8] Papadimitriou, D.B., Nikiforos, M. and Zezza, G. (2014) Prospects and Policies for the Greek Economy. http://www.levyinstitute.org/pubs/sa_2_14.pdf

[9] Niemeier, E. (2016) „Rettungsprogramme“ für Krisenländer verschärften die Krise-eine Replik. Wirtschaftsdienst, 96, 64-71. https://doi.org/10.1007/s10273-016-1927-y

[10] Meghir, C., Pisarides, C., Vayanos, D. and Vetas, N. (2017) Beyond Austerity: Reforming the Greek Economy. MIT Press, Cambridge MA.

[11] Brenke, K. (2012) Die griechische Wirtschaft braucht eine Wachstumsstrategie. DIW Wochenbericht, 5, 3-15.

[12] Haliassos, M. (2015) Greece: Are We Missing the Reform Opportunity of the Crisis? http://voxeu.org/article/greece-seizing-crisis-s-reform-opportunities

[13] Gligorov, V. (2016) The Transfer and Adjustment Problems in the Balkans. Thewiiw Balkan Observatory, Working Papers 125, The Vienna Institute for International Economic Studies, Vienna.

[14] Kritikos, A. (2014) Griechenland: Ohne den Aufbau eines Innovationssystems wird es nicht gehen. DIW Wochenbericht, 39, 907-914.

[15] Sklias, P. and Maris, G. (2013) The Political Dimension of the Greek Financial Crisis. Perspectives on European Politics and Society, 14, 144-164. https://doi.org/10.1080/15705854.2012.732392

[16] Michas, T. (2011) Putting Politics above Markets: Historical Background to the Greek Debt Crisis. Cato Working Paper Cato Institute, Washington DC.

[17] OECD (2016) OECD Competition Assessment Reviews: Greece 2017. OECD, Paris.

[18] Kotios, A., Galanos, G. and Pavlidis, G. (2011) Greece and the Euro: The Chronicle of an Expected Collapse. Intereconomics, Review of International Trade and Development, 46, 263-269. https://doi.org/10.1007/s10272-011-0390-7

[19] Arghyrou, M.G. (2015) On Greek Crisis, Growth, Market-Access and Debt Forgiveness. CESifo DICE Report, 1, 33-38.

[20] Galenianos, M. (2015) The Greek Crisis: Origins and Implications. Crisis Observatory Research Paper No 16, Hellenic Foundation for European and Foreign Policy (ELIAMEP), Athens. 
[21] Roukanas, S.A. and Sklias, P.G. (2017) The Greek Political Economy 2000-2015. Eburon, Delft.

[22] European Commission (2010) The Economic Adjustment Programme for Greece. European Economy Occasional Papers No 61, Brussels.

[23] European Commission (2012) The Second Economic Adjustment Programme for Greece. European Economy Occasional Papers No 94, Brussels.

[24] European Commission (2015) Third Memorandum of Understanding. http://online.wsj.com/public/resources/documents/greecedoc.pdf

[25] European Commission (2016) Supplemental Memorandum of Understanding. http://ec.europa.eu/economy_finance/assistance_eu_ms/greek_loan_facility/pdf/sm ou_en.pdf

[26] Kotios, A. and Roukanas, S. (2013) The Greek Crisis and the Crisis in Eurozone's Governance. In: Greece’s Horizons, Springer, Berlin, 91-105. https://doi.org/10.1007/978-3-642-34534-0_8

[27] Giavazzi, F. and Pagano, M. (1996) Non-Keynesian Effects of Fiscal Policy Changes: International Evidence and the Swedish Experience. Swedish Economic Policy Review, 3, 67-103.

[28] Alesina, A. and Perotti, R. (1997) Fiscal Adjustments in OECD Countries: Composition and Macroeconomic Effects. International Monetary Fund Staff Papers, 44, 210-248. https://doi.org/10.2307/3867543

[29] Kotios, A., Galanos, G., Plymakis, S. and Roukanas, S. (2015) The Vicious Circles of Recession and Development Prospects. Procedia Economics and Finance, 19, 63-68. https://doi.org/10.1016/S2212-5671(15)00008-8

[30] Heimberger, P. (2016) Did Fiscal Consolidation Cause the Double-Dip Recession in the Euro Area? Working Paper 130, The Vienna Institute for International Economic Studies, Vienna.

[31] Hennigan, M. (2015) Europe's Worst Exporter: Poor Export Performance of Greece. http://www.finfacts.ie/irishfinancenews/article_1028650.shtml

[32] Hanzl-Weiss, D. and Landesmann, M. (2016) Correcting External Imbalances in the European Economy. Research Report 410, The Vienna Institute for International Economic Studies, Vienna.

[33] Gros, D. (2015) Where Is the Credit Crunch in Greece? CEPS Commentary. https://www.ceps.eu/system/files/CEPS\%20Commentary\%20Credit\%20Crunch\%20 Greece\%20D\%20Gros_0.pdf

[34] Transparency International (2015) Corruption Perceptions Index 2015. https://www.transparency.org/cpi2015/

[35] World Economic Forum. The Global Competitiveness Report 2001-2016. https://www.weforum.org/

[36] World Bank (2016) Ease of Doing Business Report 2016. http://www.doingbusiness.org/ /media/WBG/DoingBusiness/Documents/AnnualReports/English/DB16-Full-Report.pdf

[37] IMF (2017) Greece Selected Issues. IMF Country Report No. 17/41, Washington DC.

[38] Ernst \& Young (2016) Tax Evasion in Greece (In Greek). http://www.dianeosis.org/wpcontent/uploads/2016/06/tex_evasion_version_240616 2.pdf

[39] Panageas, S. and Tinios, P. (2015) Pensions: Arresting a Race to the Bottom. In: 
Meghir, C., Pissarides, C., Vayanos, D. and Vettas, N., Eds., Crisis in the Euro Zone: Policy Options for Greece, MIT Press, Cambridge.

[40] Tinios, P. (2016) Greek Pension Reform Once Again: Explaining Its Logic and Issues.

http://www.lse.ac.uk/europeanInstitute/research/hellenicObservatory/CMS\%20pdf/ HO\%20staff\%20in\%20Prees/BRIEFING-NOTE-PT.pdf

[41] Poufinas, T. and Kouskouna, E. (2016) Rearranging Social Security Contributions: Alleviating the Burden of the State and Returning Value to the State and the Society, A New Growth Model for the Greek Economy: Requirements for Long-Term Sustainability. Palgrave-Macmillan, London, 201-224.

[42] Poufinas, T. and Kouskouna, E. (2017) On the Split of Social Security Contributions between Funded and Pay-As-You-Go Pension Schemes; Contribution to Growth. The Greek Debt Crisis-In Quest of Growth in Times of Austerity. Palgrave-Macmillan, London, 129-152. https://doi.org/10.1007/978-3-319-59102-5_5

[43] Bitzenis, A., Vlachos, V. and Schneider, F. (2016) An Exploration of the Greek Shadow Economy: Can Its Transfer into the Official Economy Provide Economic Relief Amid the Crisis? Journal of Economic Issues, 50, 165-196.

[44] Schneider, Fr. (2015) Tax Evasion, Shadow Economy and Corruption in Greece and Other OECD Countries: Some Empirical Facts.

http://www.amcham.gr/wpcontent/uploads/2015/taxspeeches/friedrich\%20schneide $\underline{\text { r.pdf }}$

[45] Artavanis, N.T., Morse, A. and Tsoutsoura, M. (2015) Measuring Income Tax Evasion Using Bank Credit: Evidence from Greece. The Quarterly Journal of Economics, 131, 739-798. https://doi.org/10.1093/qje/qjw009

[46] UNCTAD (2016) World Investment Report 2016. http://unctad.org/en/PublicationsLibrary/wir2016_en.pdf

[47] McKinsey \& Company (2012) Greece 10 Years Ahead, Defining Greece's New Growth Model and Strategy. McKinsey \& Company, Athens. 